\title{
First occurrence of Sivatherium Falconer and Cautley, 1836 (Mammalia, Ruminantia, Giraffidae) in the Iberian Peninsula
}

\section{María Ríos, Plini Montoya, Jorge Morales \& Gregorio Romero}

To cite this article: María Ríos, Plini Montoya, Jorge Morales \& Gregorio Romero (2021)

First occurrence of Sivatherium Falconer and Cautley, 1836 (Mammalia, Ruminantia,

Giraffidae) in the Iberian Peninsula, Journal of Vertebrate Paleontology, 41:3, e1985507, DOI:

10.1080/02724634.2021.1985507

To link to this article: https://doi.org/10.1080/02724634.2021.1985507

View supplementary material $\asymp$

曲 Published online: 09 Nov 2021.

Submit your article to this journal

Џll Article views: 88

Q View related articles $\longleftarrow$

View Crossmark data $\gtrsim$ 


\title{
FIRST OCCURRENCE OF SIVATHERIUM FALCONER AND CAUTLEY, 1836 (MAMMALIA, RUMINANTIA, GIRAFFIDAE) IN THE IBERIAN PENINSULA
}

\author{
MARÍA RÍOS, (D) *,1 PLINI MONTOYA, ${ }^{2}$ JORGE MORALES, (D) ${ }^{3}$ and GREGORIO ROMERO ${ }^{4,5}$ \\ ${ }^{1}$ Departamento de Ciências da Terra, FCT-UNL Faculdade de Ciências e Tecnologia, GeoBioTec, Universidade Nova de Lisboa, \\ 2829-516 Caparica, Portugal, maria.rios.iba@gmail.com; maria.rios.iba@fct.unl.pt; \\ ${ }^{2}$ Departament de Botànica i Geologia, Universitat de València, Doctor Moliner 50, 46100 Burjassot, Spain, pmontoya@uv.es; \\ ${ }^{3}$ Departamento de Paleobiología. Museo Nacional de Ciencias Naturales-CSIC. C/ José Gutiérrez Abascal, 2. 28006 Madrid, Spain, \\ mcnm166@mncn.csic.es; \\ ${ }^{4}$ Dirección General de Bienes Culturales de la CARM, Casa Díaz Cassou, C/ Santa Teresa 21, 30071 Murcia, Spain, gromero@um.es; \\ ${ }^{5}$ Grupo de Investigación de Geología, Facultad de Química, Universidad de Murcia, Calle Campus Universitario, 5, 30100 Murcia, \\ Spain, gromero@um.es
}

\begin{abstract}
The sivatherine clade includes some of the largest giraffids and emerged during the late Miocene. Sivatherium hendeyi, the earliest known species of the Sivatherium genus, was first described from the lower Pliocene of Langebaanweg $(5.15 \pm 0.1 \mathrm{Ma}$, Cape Province, South Africa). Here we describe the first possible occurrence of Sivatherium from western Europe from the lower Pliocene (MN14) of Puerto de la Cadena (4.9 Ma, Murcia, Spain). The new material consists of dental and postcranial remains. The Puerto de la Cadena Sivatherium, together with the presence of Macaca sp. and Debruijnimys sp., indicates a connection between African and European faunas during the early Pliocene and a possible relationship between Sivatherium and the stem Iberian sivatherines Decennatherium and Birgerbohlinia.
\end{abstract}

SUPPLEMENTAL DATA - Supplemental materials are available for this article for free at www.tandfonline.com/UJVP

Citation for this article: M. Ríos, M., P. Montoya, J. Morales, and G. Romero. 2021. First occurrence of Sivatherium Falconer and Cautley, 1836 (Mammalia, Ruminantia, Giraffidae) in the Iberian Peninsula. Journal of Vertebrate Paleontology. DOI: 10.1080/02724634.2021.1985507

\section{INTRODUCTION}

Sivatherines (Sivatheriinae Bonaparte, 1850; Harris et al., 2010) are a giraffid clade diagnosed mainly by cranial features (e.g., ossicone number, position, shape, and ornamentation), and are defined as the least inclusive clade that contains Decennatherium and Sivatherium (Ríos et al., 2017). Decennatherium from the lower upper Miocene of the Iberian Peninsula is the earliest known sivatherine as it shows the earliest known evidence for a Sivatherium-like ossicone plan, with two small, anteriorly oriented frontal ossicones and two much larger, caudally oriented and curved fronto-parietal ossicones covered by numerous deep longitudinal ridges (Ríos et al., 2017; Ríos and Morales, 2019). The chronostratigraphic and paleobiogeographic ranges of sivatherines span from the lower upper Miocene of the Iberian Peninsula to the Pleistocene of Africa, rendering them one of the most widespread and long-lived giraffid subfamilies (Ríos et al., 2017).

Among Sivatheriinae (Solounias, 2007), the genus Sivatherium includes the largest extinct giraffids, characterized by metapodials that are short with respect to their width (Harris et al., 2010). The earliest known Sivatherium is S. hendeyi Harris, 1976b, from the lower Pliocene "E" Quarry in Langebaanweg (Cape Province, South Africa) and possibly other sites (the upper Miocene of Toros Menalla [Chad, Likius, 2002], the Adu Asa and Sagantole Formations [Ethiopia, Kalb et al., 1982;

*Corresponding author

Color versions of one or more of the figures in the article can be found online at www.tandfonline.com/ujvp.
Haile-Selassie, 2009], the Lower Nawata [Harris, 2003], and from the lower Pliocene of Kanapoi [Kenya, Harris, 1976b; Harris et al., 2003; Franz-Odendaal and Solounias, 2004; FranzOdendaal et al., 2004; Roberts et al., 2011; Geraads et al., 2013; Geraads and Bobe, 2020]). Other species are Sivatherium maurusium Pomel, 1892, from the Pleistocene of Africa, Sivatherium giganteum Falconer and Cautley, 1836 from the Pleistocene of India and Pakistan (Hopwood, 1934), and Sivatherium garevskii Geraads, 2009 from the lower Pliocene of Stamer (Delcevo, Republic of North Macedonia). There is also a record of S. giganteum from Edirne (Turkey), probably of Plio-Pleistocene age (Abel, 1904:plate I:figs. 1, 2).

Four fossil giraffids are so far known from the Iberian Peninsula. The first three are stem sivatherines (Ríos et al., 2017) from the late Miocene: the early Vallesian Decennatherium pachecoi Crusafont, 1952 (Nombrevilla, Los Valles de Fuentidueña, Relea, Predajas de San Esteban, Masía del Barbo, Masía de la Roma, MN9-10; Alcalá and Montoya, 1994; Crusafont, 1952; Morales and Soria, 1981), the late Vallesian Decennatherium rex Ríos, Sánchez and Morales, 2017 (BAT4, BAT10, MN10, Ríos and Morales, 2019; Ríos et al., 2017), and the early Turolian Birgerbohlinia schaubi Crusafont, 1952 (Cerro de la Garita, Piera, Crevillente-2, Puente Minero, Masada del Valle-2, Torrentet dels Traginers, MN11-12; Alcalá et al., 1991; Crusafont, 1952; Montoya and Morales, 1991). The fourth Iberian giraffid is the smaller and more gracile Paleotragine Mitilanotherium inexpectatum Samson and Radulesco, 1966 from the terminal late Pliocene-early Pleistocene (Fonelas P1 and Huélago, MN17; Garrido and Arribas, 2008; van der Made and Morales, 2011; Athanassiou, 2014). Other 
sites in the Iberian Peninsula have yielded a few large giraffid remains that have not been conclusively identified (Montenat and Crusafont, 1970; Alcalá, 1994; Alcalá and Montoya, 1994). These include the poorly documented remains of a juvenile mandible of Decennatherium pachecoi from La Paloma (MN13; Montenat and Crusafont, 1970), the alleged Sivatheriinae indet. from the upper Miocene-lower Pliocene of Corral de Lobato (base of MN13; Morales et al., 2018) and La Alberca (MN13; Montenat and Crusafont, 1970), and cf. Birgerbohlinia from the lower Pliocene sites of La Gloria-4 and La Calera (MN14; Alcalá, 1994; Alcalá and Montoya, 1994).

The most recent findings comprise several well-preserved dental and postcranial remains of an extremely large giraffid from the lower Pliocene site Puerto de la Cadena (PdlC, MN14), tentatively identified as Sivatherium cf. hendeyi by Piñero et al. (2017).

In this work we describe these remains, analyze their biogeographic and systematic implications, and discuss other alleged sivatherine findings from the Iberian Peninsula.

\section{Locality and Geological Setting}

The site of Puerto de la Cadena is located $8 \mathrm{~km} \mathrm{SSW}$ of the town of Murcia, and $2.5 \mathrm{~km}$ south of El Palmar, on the northern flank of the Carrascoy range mountain $\left(37^{\circ} 55^{\prime} 9^{\prime \prime} \mathrm{N}, 1^{\circ} 9^{\prime} 41^{\prime \prime} \mathrm{W}\right.$, Murcia Region, SE Spain; Fig. 1). The site was discovered in 2008 during the construction of the MU-31 motorway. Puerto de la Cadena yielded a diverse vertebrate continental fauna, and so far 26 different species are recorded (faunal list in Piñero et al., 2017:table 1). The assemblage correlates to the base of the MN14, making it one of the youngest localities of the early Pliocene (4.997-4.896 Ma), and is novel for the Spanish fossil record of the Miocene/Pliocene boundary due to both age and faunal composition (Piñero et al., 2017). The area of PdlC has a rich paleontological record, known since the early 1970s (Montenat and Crusafont, 1970; Mein et al., 1973; Montenat, 1973) with sites such as La Alberca and La Paloma, which have both yielded giraffid remains of a latest Miocene/earliest Pliocene age (MN13; Aguirre et al., 1976; Aguirre and Morales, 1974; Bruijn et al., 1975; Morales and Soria, 1984).

The Cigarrón Unit at the PdlC site is formed by an alternating succession of sand and fine-grained clay-size sediments. The macrovertebrate fossil remains are mainly in the conglomeratic layers of the sands or in the basal lag of the sedimentary sets. The sand components are medium-sized to coarse siliciclastic grains with very little matrix and no cement (Piñero et al., 2017). The stratigraphical and sedimentological information indicates a continental depositional context related to fluvial systems with fluctuating flow regimes near the coast (Piñero et al., 2017). The sand and gravel beds show unidirectional cross-stratification corresponding to channels through which underwater dunes and megaripples migrated, while the fine-grained sediments interbedded between sandy beds represent floodplain deposits dominated by channel overbank processes (Piñero et al., 2017).

\section{MATERIALS AND METHODS}

The material tentatively identified as Sivatherium cf. hendeyi described in this work comprises all giraffids from PdlC. These are stored at the Archivo Intermedio-Comunidad de Murcia (Murcia, Spain).

\section{Comparative Sample}

The comparative sample includes crania and postcrania of Birgerbohlinia schaubi from Piera, Torrentet dels Traginers, and Crevillente-2 curated by the ICP (Sabadell, Spain) and the MUVHN (Burjasot, Spain), respectively. We used the material belonging to Decennatherium pachecoi from Los Valles de Fuentidueña, and the entire sample of Decennatherium rex from BAT10 and BAT4 stored at the MNCN-CSIC (Madrid, Spain). Other large sivatherine materials come from the collections curated by the AMNH (New York, U.S.A.), the MNHN (Paris, France) and the NHMUK (London, U.K.), as well as from the Iziko South African Museum (Cape Town, South Africa). These include Helladotherium duvernoyi Gaudry, 1861 from Pikermi, Axios Valley fossil sites, Samos (Greece), and Cucuron (France), from the upper Miocene of India and Pakistan Bramatherium perimense Falconer, 1845 from Perim Island (India) and Bramatherium megacephalum Lydekker, 1876 from Dhok Pathan (Pakistan), as well as the early Pleistocene Sivatherium giganteum from the upper Siwaliks of Kalka, Kharian, Nahun, Nàhan, Pinjaur, Siswan, and Chandigarh (India and Pakistan). We also collected bibliographic data of the larger giraffids Sivatherium maurusium from Koobi Fora (Kenya) and Laetoli (Tanzania; Harris, 1991; Robinson, 2011), Sivatherium olduvaiense from Olduvai and Garussi Korongo (Tanzania; Dietrich, 1937; Dietrich, 1942; Singer and Boné, 1960, previously $S$. olduvaiense, synonym of $S$. maurusium), $S$. hendeyi from Cape Province (South Africa), S. aff. hendeyi from the upper Miocene of Toros Menalla (Chad; Likius, 2002), and S. cf. hendeyi from Kanapoi (Kenya; Harris, 1976b,

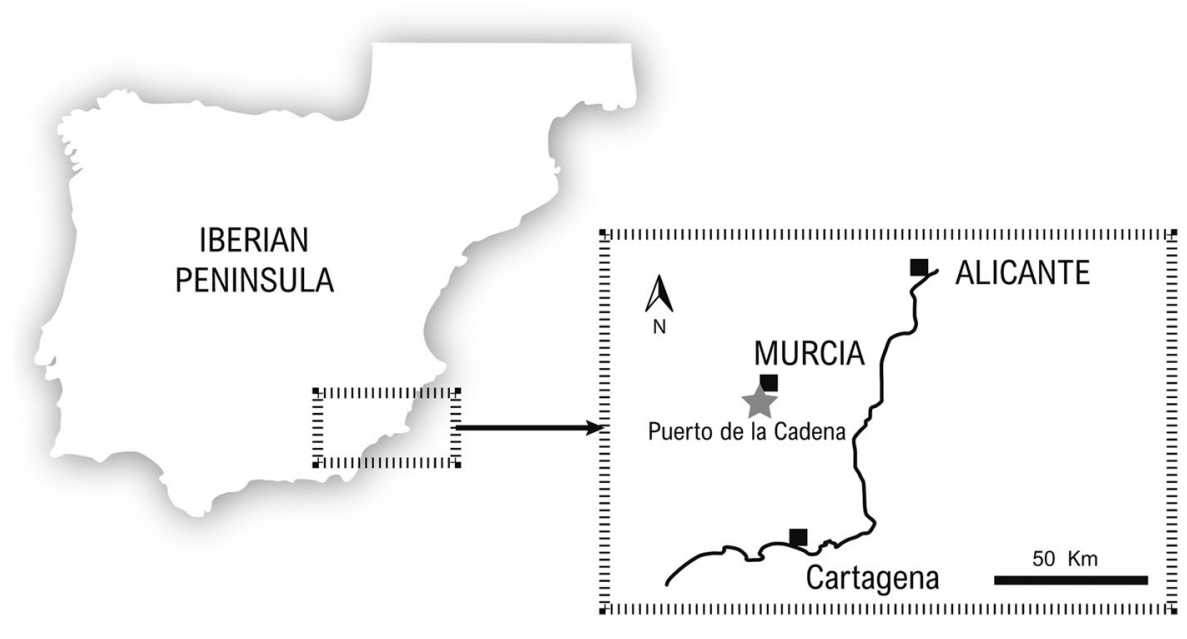

FIGURE 1. Location of Puerto de la Cadena within Spain (modified from Piñero et al., 2017). 
Harris et al., 2003; Franz-Odendaal et al., 2004; Franz-Odendaal and Solounias, 2004; Roberts et al., 2011; Geraads et al., 2013, Geraads and Bobe, 2020), as well as from other alleged Sivatheriinae findings from the Iberian Peninsula (see Introduction).

All measurements were taken with digital calipers. The raw measurements and their descriptive statistics are detailed in Tables S1-S5. We mostly follow the set of measurements proposed by Ríos et al. (2016a) for the metapodials, by Solounias and Danowitz (2016) for the astragalus, and by von den Driesch (1976) for the dentition and rest of the postcranial skeleton. We use the terminology of Bärmann and Rössner (2011) for nomenclature of the dentition, and Barone (1999) for the postcranial skeleton.

Institutional Abbreviations-AICM, Archivo IntermedioComunidad de Murcia, Murcia, Spain; AMNH, American Museum of Natural History, New York, New York, U.S.A.; BAT, Batallones; ICP, Institut Català de Paleontologia, Sabadell, Spain; IPS, Institut Paleontologia de Sabadell (ICP), Sabadell, Spain; KNM, Kenya National Museums, East Turkana, Kenya; MGUV, MUVHN, Museu de Geologia de la Universitat de València, Burjasot, Spain; MNCN, Museo Nacional de Ciencias Naturales-CSIC, Madrid, Spain; MNHN, Musèum National d'Histoire Naturelle, Paris, France; NHMUK PV, M, OR Natural History Museum, London, U.K.; PIK, Pikermi (MNHN); SAM-PQ L, South African Museum "E" Quarry, Langebaanweg, South Africa; VLP, PdIC, Puerto de la Cadena (AICM).

\section{SYSTEMATIC PALEONTOLOGY}

MAMMALIA Linnaeus, 1758

CETARTIODACTYLA Montgelard, Catzeflis, and Douzery, 1997

RUMINANTIA Scopoli, 1777

GIRAFFIDAE Gray, 1821

SIVATHERIINAE Bonaparte, 1850

SIVATHERIUM Falconer and Cautley 1836

SIVATHERIUM HENDEYI Harris, 1976b

SIVATHERIUM cf. S. HENDEYI

(Figs. 2-10)

\begin{abstract}
Specimens-These include VLP0-11, left maxillary fragment with M1; VLP2-543, right canine; VLP1-43, right P2; VLP2-940, right M3; VLP2-941, left P4; VLP2-124, M fragment; VLP4-44, axis; VLP3-552, cervical; VLP3-504A, thoracic vertebra; VLP2292, thoracic vertebra; VLP2-735, right humerus proximal epiphysis and diaphysis fragments; VLP2-726, right radius; VLP2-492, right semilunate/; VLP2-567, left semilunate/; VLP2-102, right unciform; VLP2-370, right Mc III-IV; VLP2-62, left Mc III-IV; VLP3-562, right juvenile femur without proximal and distal epiphysis; VLP2-735, femur head; VLP1-7, left astragalus; VLP3737, right astragalus; VLP2-182, right calcaneus; VLP2-682, right cubonavicular; VLP1-39, Mt III-IV diaphysis fragment; VLP3517, right digit proximal phalanx; VLP2-314, left digit proximal phalanx; VLP2-362, right digit proximal phalanx; VLP2-385, right digit proximal phalanx; VLP1-10, left digit proximal phalanx; VLP2-293, right digit distal phalanx.
\end{abstract}

\section{ANATOMICAL DESCRIPTION AND COMPARISONS}

\section{Cranium}

Upper Dentition - The P2 VLP1-43 (Fig. 2A) is longer than wide with an $\mathrm{L} / \mathrm{W}$ index of 1.11 (the $\mathrm{L} / \mathrm{W}$ index is defined as maximum anteroposterior length/maximum transverse width measured at the occlusal surface, Table S1). The buccal cone is prominent and closer to the anterior style. The anterior style seems more developed than the posterior style, although the preservation does not allow further description of the styles. The lingual cone is prominent. The lingual wall projects posterolingually. The posterolingual crista is lingually wavy. The enamel is very rugose. VLP1-43 is larger than the P2 in Decennatherium and Birgerbohlinia but these all share similar proportions and a similar development of the labial cone. VLP1-43 has thicker lingual and buccal walls, more similar to those of Sivatherium maurusium (Churcher, 1978:fig. 25.7; Geraads, 1996:fig. 1G). The P2 of $S$. garevskii from the Pliocene of Stamer (Republic of North Macedonia; Geraads, 2009), is shorter in relation to the width when compared with the specimen from PdlC.

The P4 VLP2-941 (Fig. 2B) is wider than long with an L/W index of 0.82 (Table S1, S3). The buccal cone is prominent and almost central, slightly closer to the anterior style than to the posterior style. The anterior style is more projected labially than the posterior style. In occlusal view the tooth is simple, with a medial fossette shaped as an asymmetrical half-moon. The anterolingual crista has a wavy labial edge and it is not as wide as the posterolingual crista. The posterolingual crista has a posterior division and a wavy labial edge (Fig. 4B). The enamel both buccally and lingually is rugose. Plus, buccally there is some "cement" on the labial wall.

The P4 VLP2-941 is larger than in Decennatherium rex and Birgerbohlinia schaubi (Table S3) but they all share similar proportions and a similar development of the medial fossette. The two latter species share the same division of the posterolingual crista in different degrees of development (Montoya and Morales 1991:fig. 2; Ríos et al., 2017:fig. 8), as well as a very wavy labial edge of the posterolingual crista. VLP2-941 shares with $D$. rex the asymmetrical development of the styles as they have a less developed posterior style, while B. schaubi has a more developed posterior style.

VLP2-941 differs from other late Miocene large sivatherines in some aspects, but most of them share the presence of a posterolingual crista with a posterior division, a posterolingual crista wavy edge, a large size, and rugose enamel. VLP2-941 differs from Helladotherium duvernoyi (PIK 1501), as PIK 1501 has a less developed labial cone closer to the anterior style, a more symmetrical medial fossette, and a lingual crista parallel to medial fossette lingual outline. PIK 1501 also lacks the wavy posterolingual crista edge. The features observed in PIK 1501 are also seen in Sivatherium garevskii from the Pliocene of Stamer (Republic of North Macedonia; Geraads, 2009), the P4 in which is also slightly smaller than the specimen from PdlC. The wavy edges on the posterolingual crista are present in Sivatherium maurusium from Ahl al Oughlam (Morocco) and Ileret (Kenya, Churcher, 1978:fig. 25.7; Geraads, 1996:fig. 1G), and Sivatherium giganteum from the Siwaliks (e.g., BM1624Y-8), although these taxa have more developed posterior styles and the divisions on their posterolingual cristas are projected buccally.

The $\mathrm{L} / \mathrm{W}$ index of the $\mathrm{P} 4$ from $\mathrm{PdlC}$ is within the range of Sivatherium hendeyi and $S$. maurusium while $S$. giganteum has a higher value, and S. garevskii, Giraffa camelopardalis, Honanotherium schlosseri, Decennatherium rex, Birgerbohlinia schaubi, Bramatherium megacephalum, and Helladotherium duvernoyi have lower values (Bohlin, 1926; Geraads, 2009; Kostopoulos, 2009) (Table S3).

The M3 VLP2-940 (Fig. 2C) is very worn. It is slightly longer than wide with an L/W index of 1.09 (Table S1). The buccal wall has a stronger parastyle and mesostyle and a weaker metastyle. The paracone is strong, and more developed than the metacone. The protocone and metaconule are well separated, and U-shaped lingually. The anterior lobe (24 $\mathrm{mm})$ is slightly wider than the posterior lobe $(21 \mathrm{~mm})$. The enamel is very rugose and there is a lingual cingulum. VLP2-940 is larger than Decennatherium rex and Birgerbohlinia schaubi upper molars and has wider buccal and lingual walls, a 


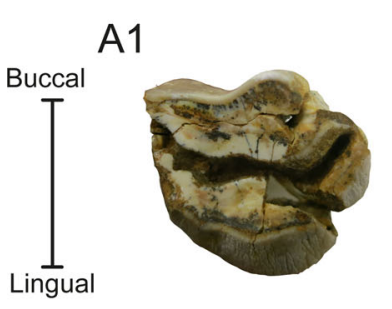

A2

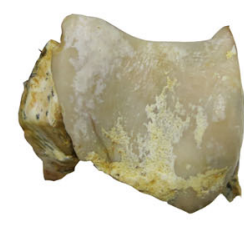

B1

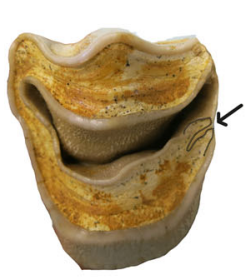

C1

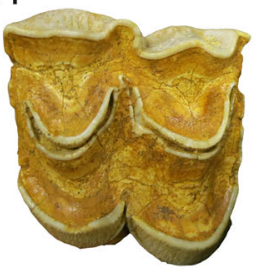

D1

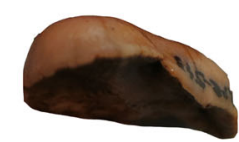

B2

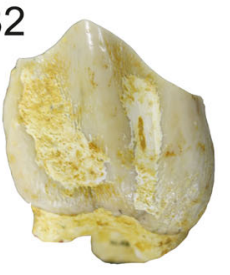

C2

D2
A3
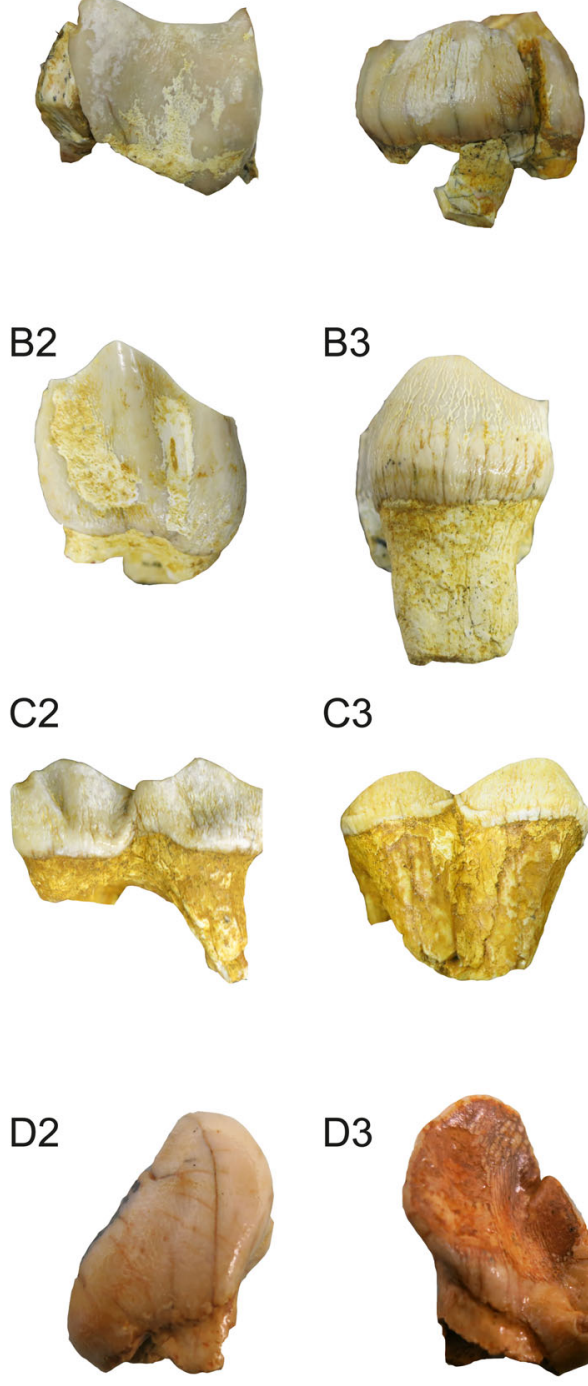

D3
B3

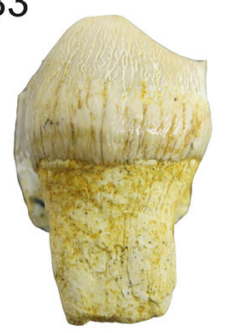

C3

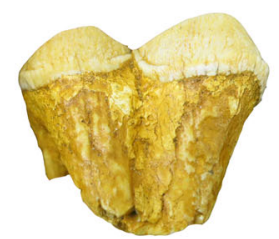

A4

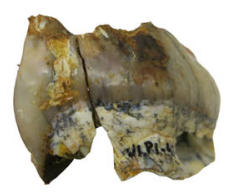

B4

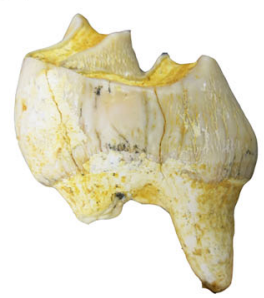

C4
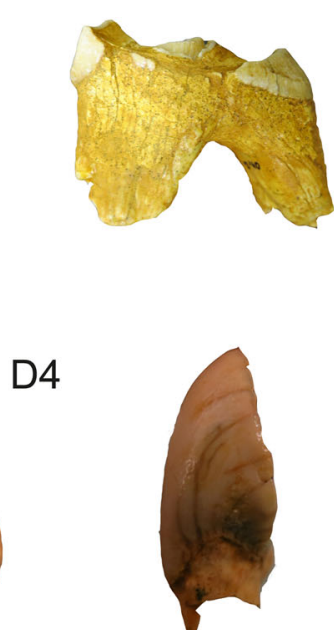

A5

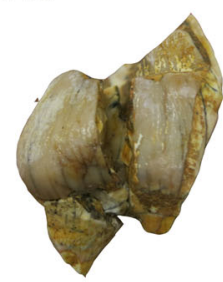

B5

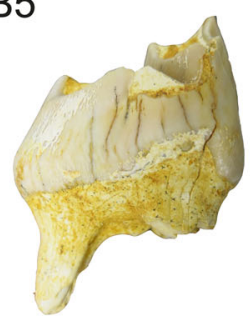

C5

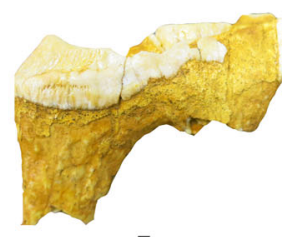

$5 \mathrm{~cm}$

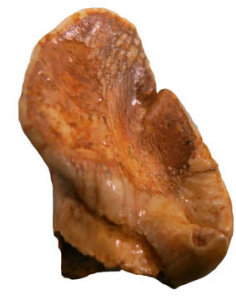

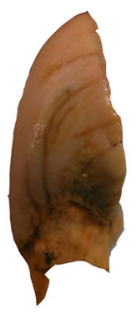

D5

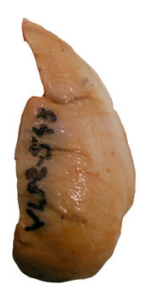

$5 \mathrm{~cm}$

FIGURE 2. Dentition of Sivatherium cf. hendeyi from Puerto de la Cadena. A, right P3, VLP1-47 in A1, occlusal view; A2, buccal view; A3, lingual view; A4, caudal view; A5, cranial view. B, right P4, VLP2-941 in B1, occlusal view; B2, buccal view; B3, lingual view; B4, caudal view; B5, cranial view. C, right M3, VLP2-940 in C1, occlusal view; C2, buccal view; C3, lingual view; C4, caudal view; C5, cranial view. D, right canine, VLP2-543 in D1, occlusal view; D2, buccal view; D3, lingual view; D4, caudal view; D5, cranial view. Arrow points to buccal incision. Scale bars equal $5 \mathrm{~cm}$. Arrow indicates division of the posterolingual crista.

narrower medial fossette and more rounded anterior and posterior lobes. Morphologically VLP2-940 is closer to Sivatherium maurusium (Churcher, 1978:fig. 25.7; Geraads, 1996:fig. 1G).

Lower Dentition - The canine (Fig. 2D, Table S1) has the distinctive second lobe diagnostic of giraffids. The larger anterior lobe is rounded and the smaller posterior lateral lobe is much shorter, pointed, and positioned diagonally from the plane of the first lobe. It is similar to the canine of Decennatherium rex, Birgerbohlinia schaubi, and Sivatherium giganteum in having a rounded anterior lobe, unlike in Giraffa camelopardalis and Okapia johnstoni where the larger lobe is pointed (Ríos et al., 2017).

\section{Postcranial Skeleton}

Axis - The specimen is very fragmentary but is similar in size to larger sivatherines. The spinous process appears well-developed. The vertebral body is not elongated as in Giraffa.

Thoracic Vertebrae-There are two thoracic vertebrae fragments in the sample (Fig. 3, Table S2). The cranial articular processes are heart shaped and located slightly anteriorly to the tip of the cranial bulge. In dorsal view, the spinous process is located posterior to the cranial articular processes and is oriented dorsocaudally. The transverse processes are thick and protrude laterally. They are located laterally and medially to the two cranial articular processes, respectively. The caudal articular processes are oval and oriented ventrocaudally. 
A1

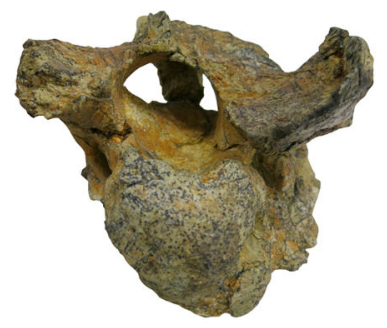

B1

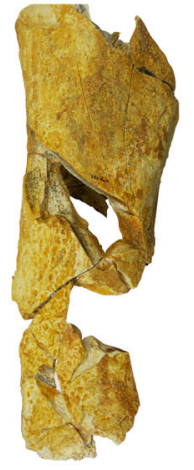

C1

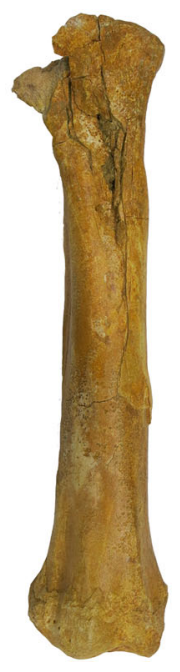

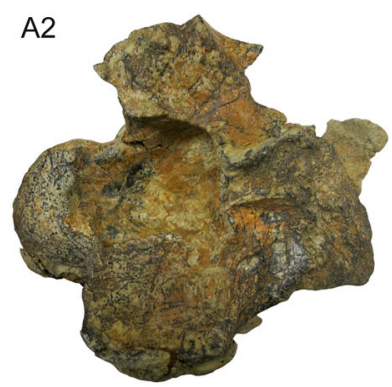

$5 \mathrm{~cm}$

B2

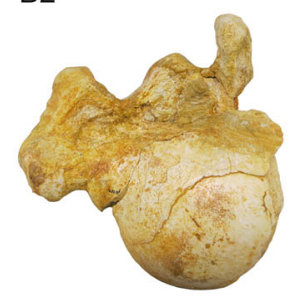

B3

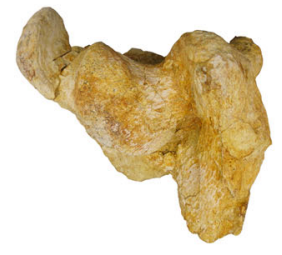

FIGURE 3. Sivatherium cf. hendeyi from Puerto de la Cadena postcranial remains. A, thoracic vertebra, VLP3-552 in A1, proximal view; A2, ventral view. B, right humerus, VLP2-735, B1, diaphysis fragment; B2, proximal epiphysis fragment in proximal view; B3, proximal epiphysis fragment in dorsal view. C, right radius-ulna, VLP2-726 in C1, dorsal view; C2, lateral view; C3, palmar view; C4, medial view; C5, proximal view; C6, distal view. Scale bars equal $5 \mathrm{~cm}$.
C2

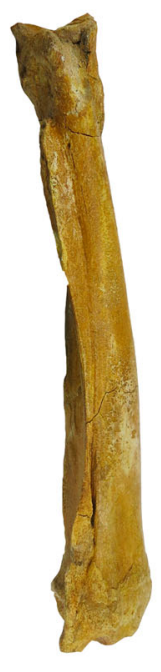

C3

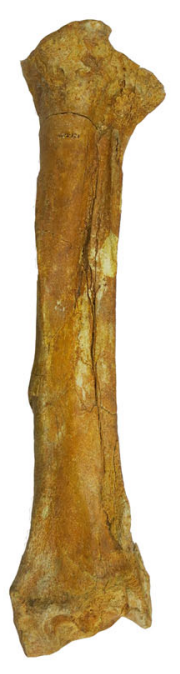

C5

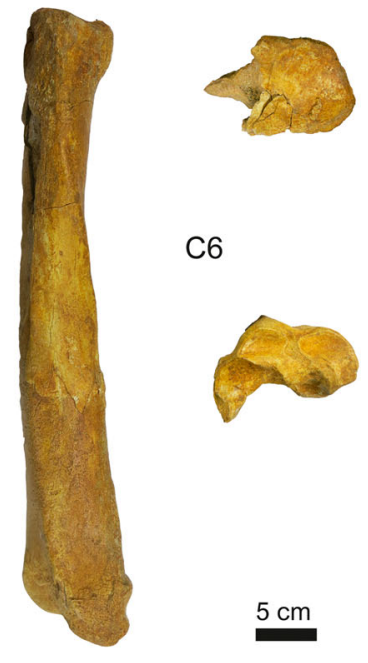

Humerus - VLP2-735 consists of a large proximal epiphysis and some diaphysis fragments (Fig. 3B, Table S2). The apex of the greater tubercle is massive, where the supraspinatus muscle inserts. The greater tubercle is large and very developed where the deep infraspinatus muscle attaches. The apex of the lesser tubercle is developed and rugose, indicating the attachment area for the subscapularis muscle. The humeral head is massive, rounded, and has a smooth surface. Distally to the head, the shaft is very rugose. The surface of the diaphysis fragment is profusely rugose.

VLP2-735 is only slightly smaller than Sivatherium giganteum from the Pliocene of Siwaliks Hills (India) and larger than the rest of the specimens in our comparative sample. This may suggest a closer affinity to Sivatherium than to any other giraffid genera. The diaphysis surface fragments have a more rugose surface than that of the $S$. giganteum and Decennatherium rex.
No proximal epiphysis of $S$. hendeyi was described so far from Langebaanweg (Harris, 1976b).

Radius - VLP2-726 is a nearly complete radius of a fairly young individual with part of the ulna fused (Fig. 3C). In dorsal view the dorsoproximal coronoid process is barely developed. In proximal view, the medial half of the humeral articulation facet is wider than the lateral half. The capitulum facet is smooth and its lateral border is rounded. The dorsoproximal surface is very rugose. This rugosity can also be seen in Sivatherium hendeyi from Langebaanweg (South Africa). On the proximomedial surface the groove for the brachialis muscle proximal attachment at the coronoid process is very deep. Posterolaterally the ulna is attached to the first two-thirds of the radius diaphysis, fusing distally with the distal epiphysis, which seems to be recently fused to the rest of the diaphysis. The scaphoid facet is smooth, convex palmarly and concave dorsally, and subrectangular in shape. Its dorsal 
A1

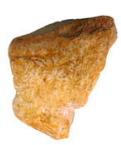

A2

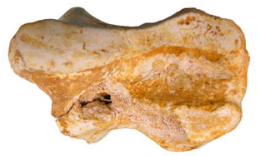

B1
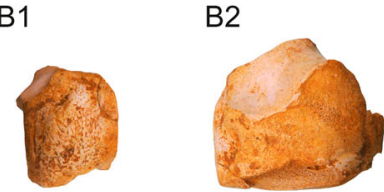

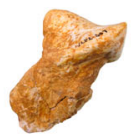

A3

B3

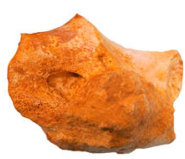

A4

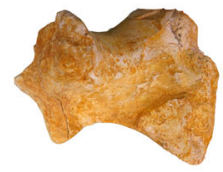

B4

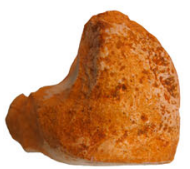

A5

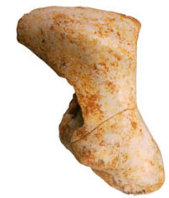

B5

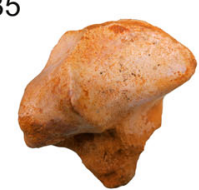

A6

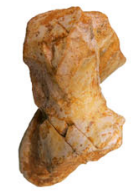

B6

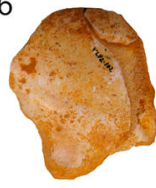

$5 \mathrm{~cm}$
C1

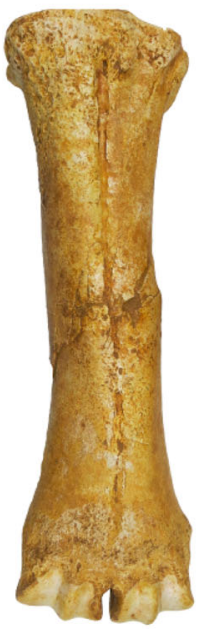

C2

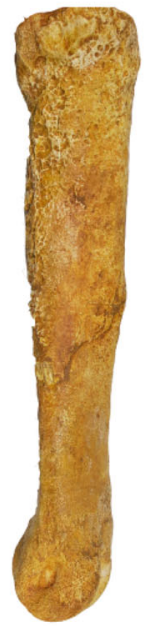

C3

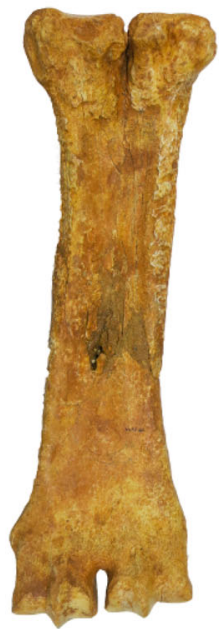

C4

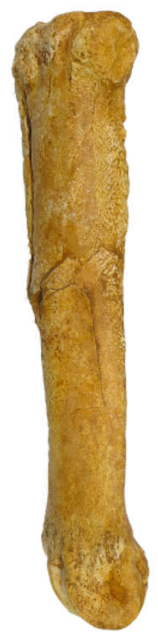

C5

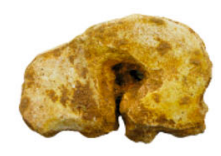

C6

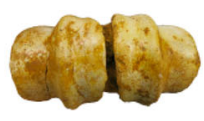

$5 \mathrm{~cm}$

FIGURE 4. Carpals and metacarpal III-IV of Sivatherium cf. hendeyi from Puerto de la Cadena. A, left semilunate, VLP2-567 in A1, dorsal view; A2, medial view; A3, palmar view; A4, lateral view; A5, proximal view; A6, distal view. B, right unciform, VLP2-102 in B1, dorsal view; B2, medial view; B3, palmar view; B4, lateral view; B5, proximal view; B6, distal view. C, left metacarpal III-IV, VLP2-62 in C1, dorsal view; C2, medial view; C3, palmar view; C4, lateral view; C5, proximal view; C6, distal view. Scale bars equal $5 \mathrm{~cm}$.

contour is straighter than that of the semilunate facet, which is completely semicircular. The semilunate facet is palmarly convex and flattens dorsally. The semilunate facet lateral and medial crests reach the palmar side of the radius forming a groove for the articulation to the carpus. The pyramidal facet is flatter and its dorsal border is similar to the scaphoid border.

VLP2-726 has a relatively slender diaphysis, but the distal and proximal epiphyses are massive (Table S2), only matching the epiphysis size of Sivatherium hendeyi and S. giganteum (Falconer and Cautley, 1836:plate 2; Harris, 1976b; e.g., BM 39539; BM 15708, Table S4). VLP2-726 shares with S. giganteum an almost identical distal surface morphology with a semicircular distal digital fossa, but they differ as $S$. giganteum has a more massively wide diaphysis in relation to the total length of the bone and a more square scaphoid facet. Sivatherium hendeyi from Langebaanweg (L2240, South Africa) is similar to VLP2-726 in the diaphysis and epiphysis size, in the proportions, and in the articular facet morphology, although the transversal crest seems to be more developed in L2240. Decennatherium rex and Birgerbohlinia schaubi are morphologically similar to VLP2-726, but their distal articular facet is less massive, and not even the largest individuals reach the dimensions of VLP2-726.
Semilunate- VLP2-567 (Fig. 4A, Table S2) matches the size and proportions of the metacarpal VLP2-62 (see description below). The proximal facet is concave, with dorsal and palmar bulges. Like in Sivatherium, Decennatherium, and Helladotherium, the dorsal facet is dorsally wider than the distal facet, while the distal facet is palmarly wider than the proximal facet. The proximomedial and distomedial facets for the articulation to the scaphoid are complete and rectangular. In lateral view the dorsoproximal facet for the pyramidal is triangular, and the distopalmar facet is rectangular and curved. The distal facet for the unciform is narrower than the magnotrapezoid facet. The keel between these two facets is blunt.

The two PdlC semilunates are morphologically very similar to those of late Miocene sivatherines but differ in being much larger. Sivatherium giganteum from the Pliocene of the Siwaliks (Pakistan) is similar in size but has a slightly shorter "neck" relative to the total length. The largest specimen from PdlC comes close to the dimensions only displayed by $S$. giganteum, while the smaller is metrically similar to Sivatheriinae indet. cf. Birgerbohlinia sp. from the lower Pleistocene of La Calera (Spain; Alcalá and Montoya, 1994), Helladotherium duvernoyi 
A

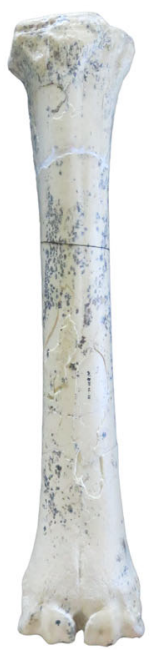

B

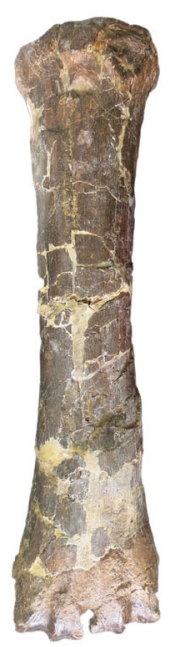

C

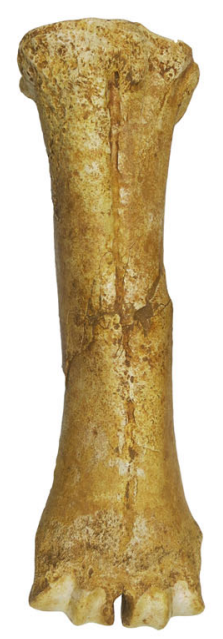

D

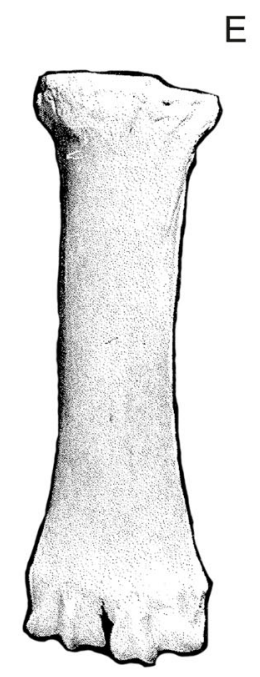

$\mathrm{E}$

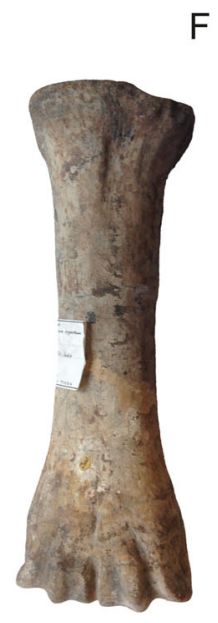

$\mathrm{F}$

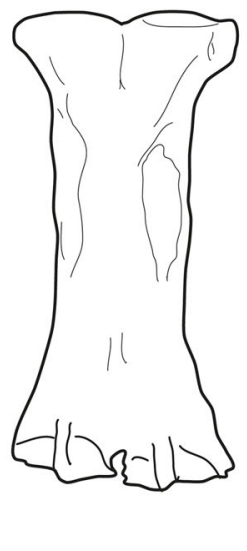

$5 \mathrm{~cm}$

FIGURE 5. Metacarpals III-IV of the giraffid species discussed (dorsal views) and their gracility parameters represented on dispersal plots. A, left metacarpal III-IV of Decennatherium rex from BAT10, BAT10'07.G2-28; B, right metacarpal III-IV of Birgerbohlinia schaubi from Crevillente-2, MGUV-7806; C, left metacarpal III-IV of Sivatherium cf. hendeyi from Puerto de la Cadena, VLP2-62; D, left metacarpal III-IV of Sivatherium hendeyi from Langebaanweg (Harris, 1976b:fig. 7A), E, left metacarpal of Sivatherium giganteum, BM-17102a; F, right metacarpal of Sivatherium maurusium (Drawing based on Harris, 1976b:fig. 7C). Scale bar equals $5 \mathrm{~cm}$.

from the upper Miocene of Pikermi (Greece), and Giraffa jumae from the lower Pleistocene of Rawi (Kenya). The specimens from PdlC are both right side semilunates, demonstrating a minimum of two individuals in our sample, one larger than the other.

Unciform - The proximal surface is semicircular and shows two distinct facets (Fig. 4B, Table S2). The proximal facet for the pyramidal is broad, lateromedially concave and wider than the facet for the semilunate. The facet for the metacarpal is smooth and slightly curved. The specimen from PdlC is only similar in size to Sivatherium giganteum and Sivatherium hendeyi, which are also similar in proportions and overall proximal morphology.

Metacarpal III-IV - There are two metacarpals, VLP2-370, a complete specimen, and VLP2-62, a proximal epiphysis and partial diaphysis. VLP2-370 (Fig. 4C, Table S2) is short, wide (with one of the lowest gracility indexes among giraffids) and shares most of the distinctive features of Sivatherium hendeyi from Langebaanweg (Fig. 7). The proximal articular surface has an open synovial fossa. The medial and lateral epicondyles are larger and more protruding than the epicondyles of Helladotherium duvernoyi, Bramatherium megacephalum, Decennatherium rex, and Birgerbohlinia schaubi, and similar in size and development to the epicondyles of Sivatherium hendeyi and Sivatherium giganteum. The lateral and medial epicondyles are asymmetrical in size and morphology, and both epicondyles flare outward.

The lateral epicondyle is larger than the medial epicondyle, as in $S$. giganteum and $S$. hendeyi, while in B. megacephalum, $H$. duvernoyi, D. rex, and B. schaubi, the medial epicondyle is larger than the lateral one. The lateral epicondyle in VLP2-370 is triangular, and dorsally shows two deep and wide oblique grooves. Palmarly the facet for the unciform extends only slightly onto the palmar surface of the lateral epicondyle and immediately below it there is a small subtriangular depression. The extension of the unciform facet into the proximopalmar area is similar in $S$. hendeyi, $S$. giganteum, and $D$. rex, while in $B$. schaubi the unciform facet extends further into the proximopalmar area reaching its maximum extension in B. megacephalum, whereas in $H$. duvernoyi it barely extends at all. As for the palmar depression below the unciform facet, it is present in $B$. schaubi (where it is larger), D. rex, and $S$. giganteum and absent in $B$. megacephalum and $H$. duvernoyi.

The medial epicondyle is smaller and rounded. Palmarly it has two grooves on the surface that separate the epicondyle into two elevated areas. The medial groove is deeper than the lateral one. Between them there is a small but deep fossa. This fossa is similar in $S$. hendeyi and B. schaubi, much larger in B. megacephalum, fainter in $D$. rex and $H$. duvernoyi, and absent in $S$. giganteum.

There is a very deep groove separating the medial and lateral epicondyles, which continues onto the central trough. There are two bony protrusions on each side of the groove. The medial protuberance is smaller in area but more prominent than the lateral one, as in $S$. hendeyi. These two proximopalmar bony protrusions are not as developed in $H$. duvernoyi, while in $B$. megacephalum, B. schaubi, and $D$. rex only the medial protrusion is developed.

The medial ridge is rounded, rugose and is separated from the medial epicondyle by an oblique groove that runs towards the central trough. This groove is also present in $S$. hendeyi and $D$. rex, is present but fainter in B. schaubi and completely absent in $H$. duvernoyi and B. megacephalum.

The lateral ridge is sharper and is separated from the lateral epicondyle by a narrow deep grove that does not continue onto the central trough. The palmar central trough is very deep proximally, and it flattens towards the distal shaft. The trough is similar in depth to $S$. hendeyi, S. giganteum, B. schaubi, $B$. megacephalum, and $H$. duvernoyi, while it is shallower in $D$. rex. The central trough in VLP2-62 is slightly less deep than in VLP2-370, and the diaphysis has very rugose lateral and medial ridges.

The metacarpal is one of the most diagnostic postcranial bones in giraffids (Ríos et al., 2016a). When comparing our specimens to those of other giraffid taxa (Figs. 5, 6), their proximal and diaphysis widths relative to their total length (diaphysis TD/total length; proximal TD/total length, respectively) indicate that they belong to Sivatherium, and are closest to $S$. hendeyi (Fig. 5, Table S5). Sivatherium maurusium and S. giganteum have even shorter and wider metapodials (Fig. 5E, F), exhibiting the lowest metapodial gracility and the maximum length shortening 

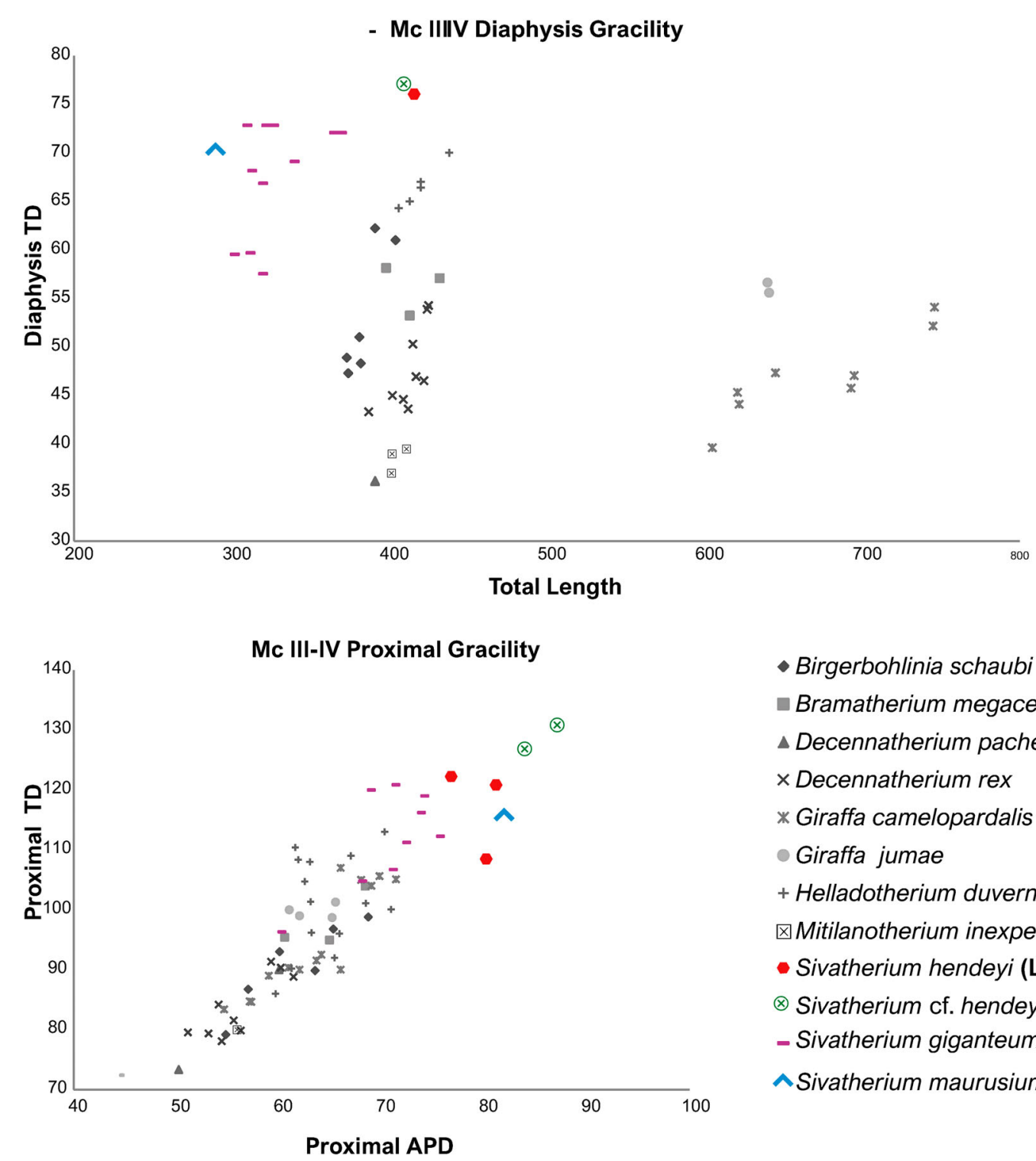

- Birgerbohlinia schaubi

- Bramatherium megacephalum

$\triangle$ Decennatherium pachecoi

$\times$ Decennatherium rex

* Giraffa camelopardalis

- Giraffa jumae

+ Helladotherium duvernoyi

$凶$ Mitilanotherium inexpectatum

- Sivatherium hendeyi (Langebaanweg)

$\otimes$ Sivatherium cf. hendeyi (Puerto de la Cadena)

- Sivatherium giganteum

^Sivatherium maurusium

FIGURE 6. Dispersal plots representing giraffid metacarpal III-IV biometric parameters. Above: Metacarpal III-IV diaphysis transverse diameter vs total length. Below: Metacarpal III-IV proximal transverse diameter vs proximal antero-posterior diameter. Measurements given in mm. Abbreviations: APD, antero-posterior diameter; TD, transverse diameter.

seen in giraffids (Fig. 6). The earlier genera Decennatherium and Birgerbohlinia from the late Miocene already show a trend towards a lower metapodial gracility and metapodial shortening. This is seen in the Iberian fossil record in the metapodials from the Vallesian D. pachecoi to the Turolian B. schaubi (Ríos et al., 2017), but none of the shortest and stoutest B. schaubi metapodials reaches the extent of shortening seen in the PdlC giraffid (Figs. 5, 6). The specimens from PdlC, as occurs only with the South African $S$. hendeyi, have massive proximal and distal epiphysis with deep posterior troughs (Figs. 5, 6; Ríos et al., 2017).

Femur-VLP3-562 (Fig. 7A) is an almost complete diaphysis of a juvenile specimen, demonstrated by the characteristic suture line of a yet unfused epiphysis. The neck of the femur is concave and has a rugose surface. Medially below the neck of the femur the diaphysis is rugose. The lesser trochanter is also developed and rugose. This is the area where the iliacus and psoas major muscles insert. Caudally, the intertrochanteric crest is very strong. The femur head is rounded (VLP2-735; Fig. 7B). The diaphysis proportions are close to those of Decennatherium rex, but the size of the caput femoris is only close to Sivatherium giganteum from the Pliocene of India (NHMUK-39545) and Helladotherium duvernoyi from the upper Miocene of Pikermi (Greece, PIK-2748).

Calcaneus-Specimen VLP2-182 (Fig. 7C, Table S2) is massive. The dorsal outline of the calcaneus body is slightly convex. The plantar border is concave, widening and forming a large bump just above the distal end. All the lateral surface of the calcaneus body is thick and has a rough surface. The proximal and lateral prominences for tendinous proximal attachment of the tuber calcanei are massive and slightly asymmetrical. In proximal view the tuber calcanei is heart-shaped. It has a large plantar groove and a rugose and developed transversal rim at the attachment area for the calcaneal tendon. The sustentaculum talus has a convex proximal border and a rounded and concave distal border. The prominent fibular facet is divided into a larger proximal convex facet and 
FIGURE 7. Femur and tarsals of Sivatherium cf. hendeyi from Puerto de la Cadena. A, right femur, VLP3-562 in A1, dorsal view; A2, medial view; A3, palmar view; $\mathbf{A 4}$, lateral view; A5, proximal view; A6, distal view. B, femur head, VLP2-735. C, right calcaneus, VLP2-182, in C1, dorsal view; C2, medial view; C3, palmar view; C4, lateral view; C5, proximal view; C6, distal view. D, left astragalus, VLP1-7 in D1, dorsal view; D2, medial view; D3, palmar view; D4, lateral view; D5, distal view. E, right cubonavicular, VLP2-682 in E1, dorsal view; E2, medial view; E3, palmar view; E4, lateral view; E5, proximal view; E6, distal view. Scale bars equal $5 \mathrm{~cm}$.
A1

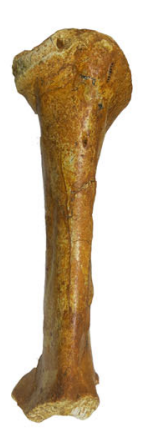

C1

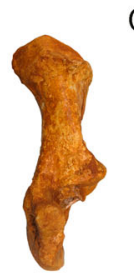

D1

A2

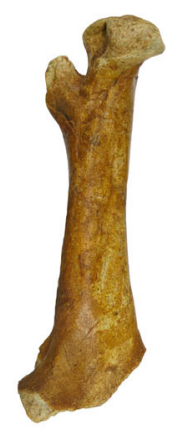

C2

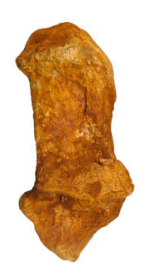

D2

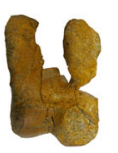

E1

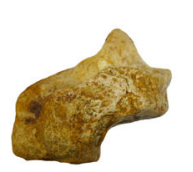

A3

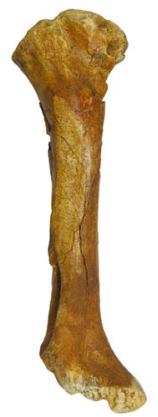

A4

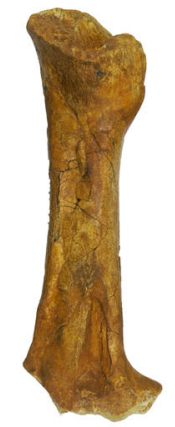

A5

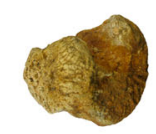

A6

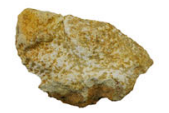

B

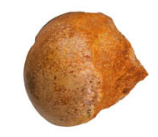

$\underline{5 \mathrm{~cm}}$
C3

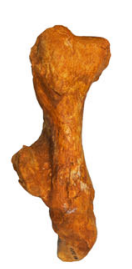

C4

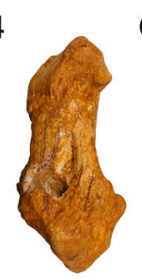

C5

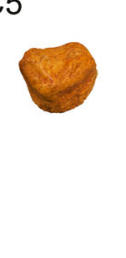

D5

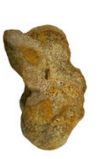

C6

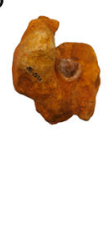

D3

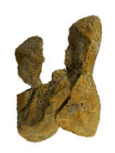

E3

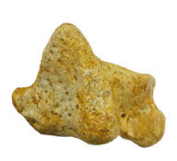

E4

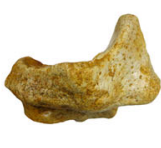

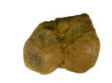

$5 \mathrm{~cm}$ a distal, shorter and slightly concave facet. Distally, the facet for the cubonavicular is almost semicircular. Among the comparative sample, the specimen from PdlC only matches the largest giraffid taxa, such as Sivatherium giganteum from the Pliocene of the Siwaliks, the early Pliocene $S$. hendeyi and Giraffa jumae from Cape Province, and Helladotherium duvernoyi from the upper Miocene of Pikermi and Salonique (Greece), Maragha (Iran), Cimişlia (Moldova), and Curcuron (France).

Astragalus - There are two fragmented astragali in our sample (VLP1-7, VLP3-737; Fig. 7D, Table S2). In dorsal view the proximal trochlea is longer than the distal one, which is typical of giraffids. In dorsal view, the lateral ridge of the trochlea is thicker than the medial ridge. The medial side of the astragalus is not distally aligned with the lateral one making the medial head lower (Fig. 7D). The central fossa is deep and oval. The groove between the medial head and medial collum tali is shallow. In medial view the fossa located in the distal area of the medial surface is relatively deep. In lateral view, the proximal protrusion that articulates with the fibula is large. In plantar view there is no discernible distal intracephalic fossa. In distal view the medial lip of the distal trochlea is shorter than the lateral one and has a more rounded distal border.

Both astragali are box shaped and notably wide, and share several morphological features with Sivatherium giganteum (Solounias and Danowitz, 2016), but they are not as wide as the astragali found in later Plio-Pleistocene Sivatherium taxa.
The distal transverse diameter is similar to that of other early Sivatherines such as Decennatherium rex and Birgerbohlinia schaubi, and also falls close to the smaller range of the $S$. hendeyi sample from Cape Town. Sivatherine astragali tend to be larger in fully adult specimens (Harris, 1976b) and the finding of a juvenile femur may suggest the presence of other postcranial juvenile elements in the sample. This may explain the slightly smaller size of the astragali in the sample.

Navicular-cuboid-Specimen VLP2-682 is very large (Fig. $7 \mathrm{E}$, Table S2). The proximal articulation for the astragalus is subrectangular, with a shorter lateral facet. The lateral facet for the calcaneus is long and wide with a curved lateral edge, which almost reaches the dorsal border of the bone. In medial view the plantar border is irregular and very rugose and there is a mediodistal tuberosity. In lateral view there is a massive distoplantar tuberosity and an attachment groove for the peroneus longus muscle. This groove is wide, wellmarked, and more developed than in other earlier sivatherines such as Decennatherium rex. Distally there is a step between the facet for the ectomesocuneiform and the facet for the entocuneiform. The dorsal facet for the metatarsal is kidneyshaped. The medial facet for the ectomesocuneiform is also kidney-shaped and the entocuneiform facet is convex and oval. On the plantar side there is a well-developed proximoplantodistal process. On this process there is an inclined crest that extends throughout the entire plantar surface. 
A1

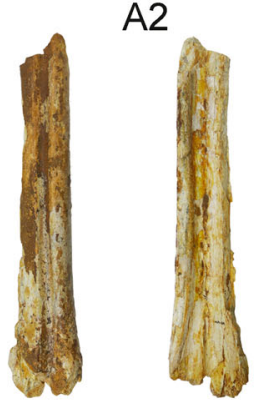

$5 \mathrm{~cm}$
B1

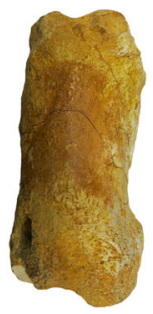

C1

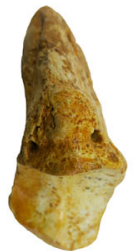

B2

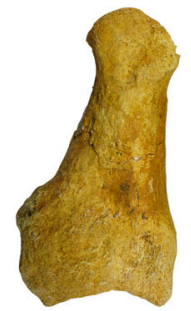

C2

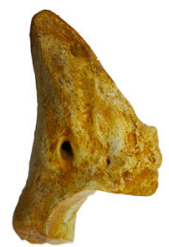

B3

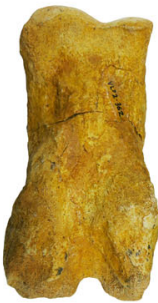

C3

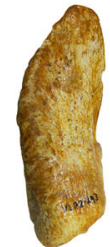

B4

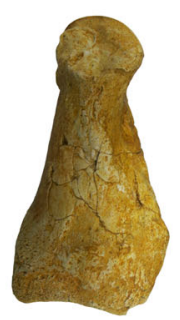

C4

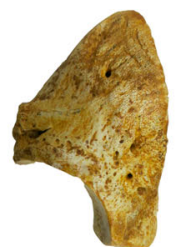

B5

B6
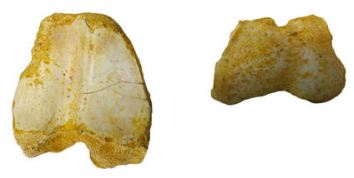

C5

C6
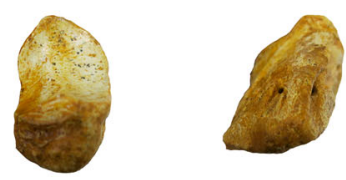

$5 \mathrm{~cm}$

FIGURE 8. Metatarsal III-IV and phalanges of Sivatherium cf. hendeyi from Puerto de la Cadena. A, metatarsal III-IV, VLP1-39 in A1, dorsal view; A2, plantar view. B, right digit proximal phalanx, VLP2-362 in B1, dorsal view; B2, medial view; B3, palmar/plantar view; B4, lateral view; B5, proximal view; B6, distal view. C, right digit distal phalanx, VLP2-293 in C1, dorsal view; C2, medial view; C3, palmar/plantar view; C4, lateral view; C5 and C6, distal view. Scale bars equal $5 \mathrm{~cm}$.

The specimen from PdlC is one of the largest of all the giraffid sample compiled for this study overlapping with the smaller Sivatherium giganteum specimens from the Pliocene of the Siwaliks (India) and the largest within the Helladotherium duvernoyi sample from the upper Miocene of Pikermi (Greece), it also falls within the average values of $S$. hendeyi in both size and proportions (TD/APD 1).
Metatarsal III-IV - Specimen VLP1-39 consists of a single diaphysis fragment of smaller dimensions (Fig. 8A). It is more gracile than the metacarpals, with a diaphysis width similar to Decennatherium pachecoi and narrower than Bigerbohlinia schaubi, Sivatheirum giganteum, Helladotherium duvernoyi, and Bramatherium megacephalum. The common digital artery runs superficially on the dorsal surface of the metatarsal III-IV
A

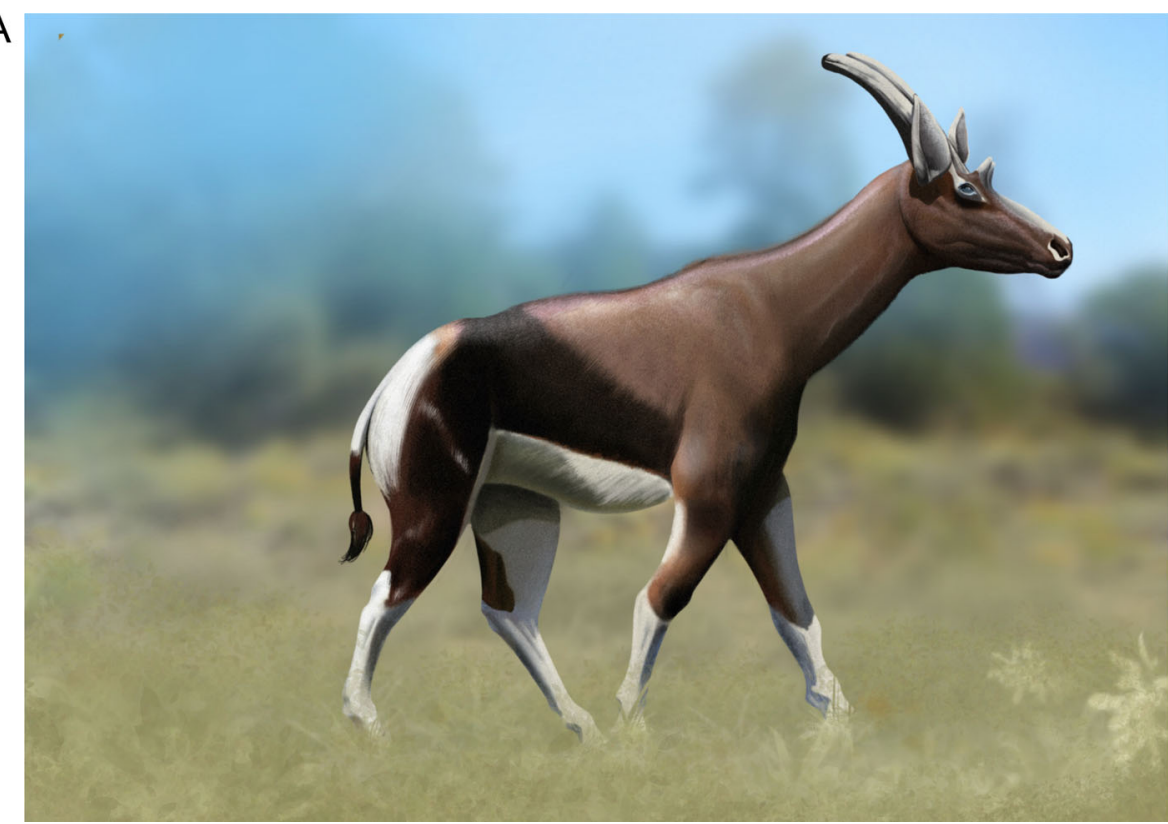

B

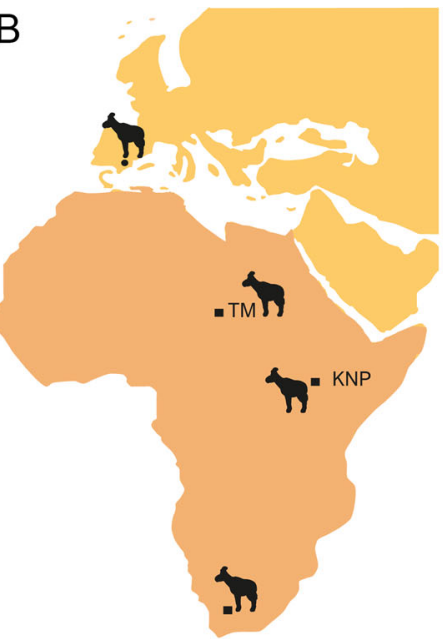

LATE MIOCENE -EARLY PLIOCENE

FIGURE 9. A, life reconstruction of an adult male Sivatherium hendeyi based on the holotypes and paratypes from Langebaanweg. Illustration by Rubén Guerrero. B, geographic distribution of paleontological sites with Sivatherium hendeyi, $S$. cf. hendeyi, and $S$. aff. hendeyi. Symbol at top: Puerto de la Cadena (4.997-4.896 Ma). Symbol at bottom: Langebaanweg (5.15 $\pm 0.1 \mathrm{Ma}$ ). Abbreviations: KNP: Kanapoi (Kenya, Harris et al., 2003; Geraads et al., 2013, Geraads and Bobe, 2020); TM: Toros Menalla (Chad, Likkius, 2002). Based on Late Miocene paleomap from Popov et al. (2004). 
A

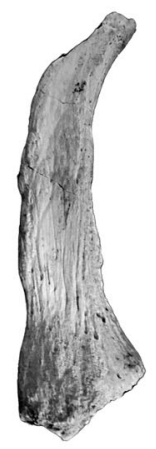

B

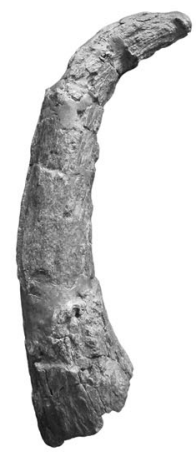

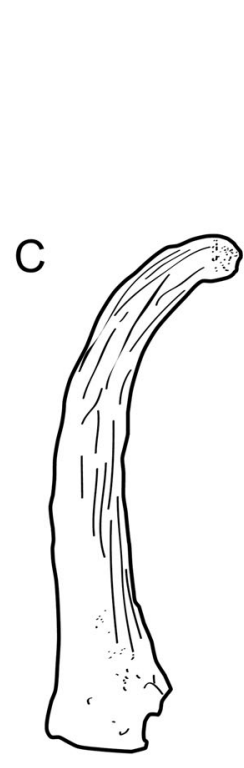
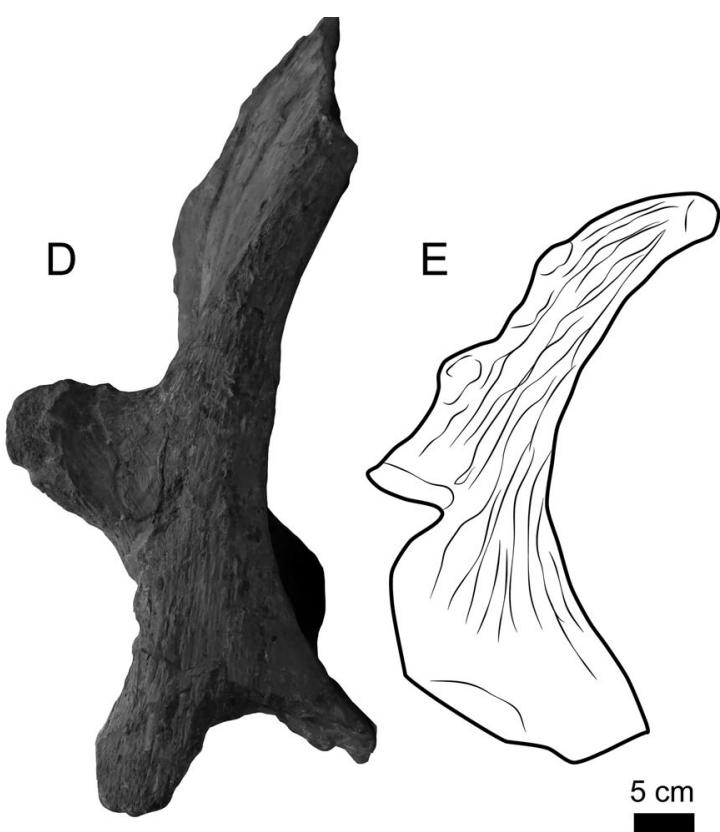

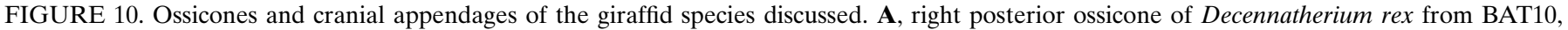

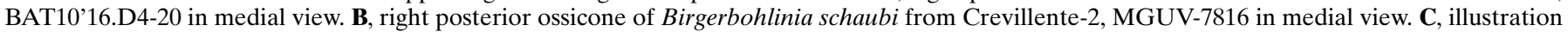

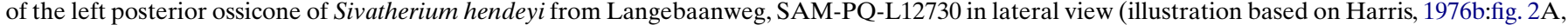

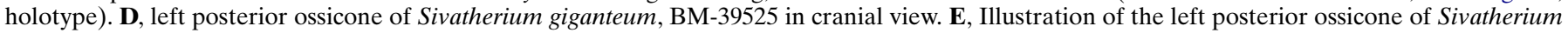
olduvaiense, M14955 in posterolateral view (illustration based on Pomel, 1892:plate 3A-B). Scale bar equals 5 cm.

within a canal (the metatarsal sulcus) that is very wide and distally open, as in $S$. hendeyi. The metatarsal plantar trough is very deep as in $S$. hendeyi and $B$. schaubi, and differs from $D$. rex and $S$. giganteum, which have shallower posterior plantar troughs.

Proximal Phalanx - There are five complete specimens in the sample, three right digits (VLP3-517, VLP2-362, VLP2-385) and two left digits (VLP2-314, VLP1-10, Table S2). In dorsal view they share a wider proximal part and a narrower distal end. In both lateral and dorsal view, the phalanges are transversally wide proximally and distally (Fig. $8 \mathrm{~B}$ ). In proximal view they share an asymmetrical proximal facet, with an inclined inter-digital half and a lateral half with a straight border. The central groove is wide. The palmar/plantar surface lacks the rugose bulges present in Decennatherium rex. The interdigital surface also lacks the rugose areas where the interdigital ligament attaches. The distal articulation is rounded from its lateral aspect and its facet is not visible from the dorsal view. The distal joint is trapezoidal and asymmetric with the lateral half slightly wider than the inter-digital one. VLP2-362 (Fig. 8B) is the most massive, surpassing the maximum length of Helladotherium duvernoyi and Bramatherium megacephalum, and only being comparable in size and gracility to the later and larger Sivatherium giganteum and Sivatherium maurusium. VLP3-517 and VLP2-385 are slightly shorter and only slightly more gracile and fall within the range of the large late Miocene sivatherine taxa $H$. duvernoyi and B. megacephalum. All the above-mentioned PdlC specimens are so wide that they show an almost rectangular outline from a dorsal view. The smaller specimens, VLP2-314 and VLP1-10 correspond to younger individuals as there is a suture line between the proximal epiphysis and the diaphysis.

Third Phalanx - In both lateral and dorsal view, the third phalanx is short and transversally narrow (VLP2-293; Fig. 8C, Table S2). From a lateral view they have a subtriangular outline. There is a well-developed dorsal process with an almost horizontal surface for the insertion of the extensor digitorum (longus or comunis depending on whether it is the anterior or the posterior phalanx). This dorsal process is as prominent as in Decennatherium rex and more prominent than in Giraffa camelopardalis. The articular facet is rounded, with the exterior part larger than the inter-digital part. Both are concave and inclined towards the inter-digital side of the phalanx. The plantar process for the insertion of the deep flexor tendon is barely developed. Proximally there is a small facet for the distal sesamoid. The plantar surface of the phalanx has the shape of an isosceles triangle.

\section{Comparisons}

The dental and postcranial elements of the giraffid from PdlC are massive, and represent the largest giraffid remains found so far in the Iberian Peninsula. The specimens analyzed are only comparable in size and proportions to the massive Sivatherium, with the forelimb reaching $\sim 1.7 \mathrm{~m}$ in length.

The dentition indicates a closest affinity to the genus Sivatherium (e.g., size, P4 wavy posterolingual crista labial edge), also sharing some close similarities with earlier sivatherine taxa found in the Iberian region: Decennatherium rex and Birgerbohlinia schaubi (e.g., P4 division of the posterolingual crista, wavy posterolingual crista labial edge; Fig. 2). As with the teeth of $S$. hendeyi from Langebaanweg, the dental remains from PdlC are morphologically indistinguishable from those of $S$. maurusium and similar in size to $S$. maurusium teeth from the nearby but later locality of Elandsfontein (Harris, 1976a). In order to differentiate between Sivatherium taxa when the ossicones are absent, we have to rely on postcranial morphology, which has already proven very useful in this regard (Ríos et al., 2016b).

As with the dental elements, the postcrania from PdlC also points to a closest affinity to Sivatherium. The humerus has similar proportions and size to $S$. hendeyi, only slightly smaller 
than those of the later $S$. giganteum. The radius has a massive epiphysis only comparable to the epiphysis of $S$. giganteum and S. hendeyi (Falconer and Cautley, 1836:plate 2; Harris, 1976a, 1976b). The same occurs with the carpals, the metacarpal, most tarsals, and the phalanges. These elements only match the size and morphological features of Sivatherium taxa (see descriptions above) and are significantly larger and less gracile than B. schaubi and D. rex (Fig. 6). The evidence of juvenile elements (e.g., femur, metatarsal) in the sample may explain the slightly smaller size of some of the other more compact elements (e.g., astragalus), although this difference in size falls within the range of giraffid natural intraspecific variation (Singer and Boné, 1960).

The element that allows us to tentatively identify these remains is the metacarpal III-IV (Figs. 5, 6). Metapodials are highly diagnostic bones (Ríos et al., 2016a) and the PdlC metacarpals III-IV in fact show a series of morphological features that point towards the identification of these remains as Sivatherium cf. hendeyi and help exclude similar sized taxa as B. megacephalum and $H$. duvernoyi (e.g., larger and more protruding medial and lateral epicondyles, lateral epicondyle larger than the medial epicondyle, extension of the unciform facet into the proximopalmar area, palmar depression below the unciform facet, palmar fossa between the two grooves of the medial epicondyle is smaller and rounded). The proportions of the metacarpals III-IV from PdlC also exclude other more gracile late Miocene sivatherines such as D. rex and B. schaubi, but also exclude the even shorter and less gracile metapodials of the Plio-Pleistocene Sivatherium taxa Sivatherium giganteum and Sivatherium maurusium (Figs. 5, 6). Bramatherium megacephalum and $H$. duvernoyi smaller specimens overlap in length with the metacarpals III-IV from PdlC but their average values are higher and also differ in many proximopalmar morphological features (see above). The late Miocene Iberian basal sivatherines D. rex and B. schaubi show a trend towards shortening and lower metapodial gracility but they do not reach the extent of the PdlC giraffid (Figs. 5, 6). It is worth noting though that B. schaubi shares with the specimens from PdlC a very similar deep posterior trough.

Finally, the smaller and more gracile Plio-Pleistocene Iberian paleotragine Mitilanotherium inexpectatum does not belong to the clade from PdlC (e.g., metacarpal III-IV Proximal TD is an average of 74.05 for $M$. inexpectatum and 128.76 for $S$. cf. hendeyi from PdlC, Table S5; van der Made and Morales, 2011; Athanassiou, 2014).

The analysis of the overall features of the dental and postcranial elements of the giraffid from PdlC indicate that the remains described in this paper represent a minimum of two individuals (one of them juvenile) of a massive extinct sivatherine that belongs to Sivatherium and here is tentatively identified as Sivatherium cf. hendeyi (Fig. 9A) on the basis of numerous morphological postcranial similarities.

\section{DISCUSSION}

\section{Biogeographic and Systematic Implications}

The Puerto de la Cadena specimens represent the first occurrence of Sivatherium from the Iberian Peninsula, and only the third Eurasian record of the genus after $S$. garevskii and $S$. giganteum (Abel, 1904; Geraads, 2009). The earliest known records of Sivatherium are S. hendeyi Harris, 1976b, from the lower Pliocene "E" Quarry in Langebaanweg (Cape Province, South Africa) and possibly other sites (the upper Miocene of Toros Menalla [Chad; Likius, 2002], the Adu Asa and Sagantole Formations [Ethiopia; Kalb et al., 1982; Haile-Selassie, 2009], the Lower Nawata [Harris, 2003], and from the lower Pliocene of Kanapoi [Kenya; Harris, 1976b, Harris et al., 2003; Franz-
Odendaal et al., 2004; Franz-Odendaal and Solounias, 2004; Roberts et al., 2011; Geraads et al., 2013, Geraads and Bobe, 2020]), suggesting an African origin for the genus (Fig. 9B). The new finds from PdlC challenge this scenario.

As mentioned in previous studies (Ríos et al., 2017; Ríos and Morales, 2019) ossicone similarities suggest a close relationship between $S$. hendeyi and the Iberian giraffids Decennatherium rex and Birgerbohlinia schaubi, leading to their classification as basal sivatherines.

The presence of Sivatherium at PdlC suggests a scenario whereby $D$. rex, which had simpler ossicones and more slender limbs, would have been followed by forms with progressively shorter, wider, and less gracile limbs (Fig. 5), with deeper posterior troughs, wider epiphyses, and massive cranial headgear with increasingly more complex secondary bone apposition. The Langebaanweg and PdlC sivatherines would fall in the intermediate stage of this scenario, as these had extremely shortened and massive limbs but ossicones lacking the large bumps, secondary bone expansions and ornamentations seen in later and larger taxa as $S$. giganteum or $S$. maurusium.

The presence of Sivatherium in the southeast of the Iberian Peninsula may imply a possible dispersal of the ancestors of $S$. hendeyi or $S$. hendeyi itself from the Iberian Peninsula to Africa (Scenario A). The other possibility (Scenario B) is an African origin for $S$. hendeyi from an as yet unknown giraffid, with a later dispersal to the Iberian Peninsula. The existence of connections between Africa and the Iberian Peninsula during the Messinian Salinity Crisis is well documented, and in PdlC there are several faunal elements of African origin such as Debruijnimys, Macaca, Alatochelon, and Plesiogulo (Piñero et al., 2017; Alba et al., 2018; Pérez-García et al., 2020; Valenciano and Govender, 2020). This, added to the younger age of PdlC, could provide support for Scenario B. However, a potential African ancestor for Sivatherium remains elusive, as the only well-known African giraffids prior to Sivatherium hendeyi are rather primitive, small, and with very different ossicone patterns (Solounias, 2007). An origin from the Giraffokeryx or Bramatherium lineages from the Siwaliks of Pakistan is not likely as the position of the ossicones in the skull roof and the postcranial morphology of Giraffokeryx differ greatly from those in Sivatherium, and Bramatherium also differs greatly from Sivatherium in both cranial and postcranial morphological features (Ríos et al., 2017). In contrast, Decennatherium rex and Birgerbohlinia schaubi represent potential ancestral taxa for Sivatherium on the Iberian Peninsula, supporting Scenario A. More evidence in favor of Scenario A comes from the phylogenetic analysis of Ríos et al. (2017), in which S. hendeyi actually appears closer to B. schaubi than to later Sivatherium species, bringing up the question whether $S$. hendeyi belongs in Sivatherium at all.

\section{Other possible Iberian Sivatherine Remains}

Most specimens potentially referable to Sivatheriinae from the upper Miocene-lower Pliocene of Aragon in northeastern Spain fall within the range of the larger Birgerbohlinia schaubi individuals from Crevillente-2. The distal metatarsal from Corral de Lobato (Molina de Aragón; Morales et al., 2018) clearly belongs to a taxon within the Birgerbohlinia-Helladotherium medium-large giraffid size range rather than the larger Sivatherium. The same is true of remains assigned to cf. Birgerbohlinia from La Calera (MN14, Teruel; Alcalá and Montoya, 1994). Though this giraffid has a semilunate that falls within the lower size range of large sivatherines, its metacarpal is to the largest specimens of Birgerbohlinia in size, and its proximal proportions are much more gracile than those of Sivatherium hendeyi. As for cf. Birgerbohlinia from the lower Pliocene of La Gloria-4 (MN14, Teruel; Alcalá, 1994; Alcalá and Montoya, 1994), its 
astragalus falls within the size range of the largest $B$. schaubi and smallest $S$. hendeyi individuals. The same is true of the astragalus of the giraffid found at La Alberca (MN13; Montenat and Crusafont, 1970). In summary, the scarcity of material from these sites does not allow us to clearly identify them beyond subfamilial level. However, due to the similar size added to the geographic and chronological closeness, some of these findings may be related to the giraffid found in PdlC, especially the specimens found in La Alberca (Murcia).

\section{CONCLUSIONS}

The giraffid from Puerto de la Cadena represents the first evidence of Sivatherium in Western Europe and possibly the first evidence of Sivatherium hendeyi outside of the African continent. The dental and postcranial remains demonstrate the presence of at least two individuals, one of them a juvenile. The new remains suggest a possible relationship between the late Miocene Iberian basal sivatherines Decennatherium and Birgerbohlinia and the genus Sivatherium, and a possible Iberian origin for this genus.

\section{ACKNOWLEDGMENTS}

MR thanks the Stimulus of Scientific Employment, Individual Support - 2018 Call grant by the Fundação para a Ciência e a Tecnologia (Portugal, CEECIND/02199/2018) and GeoBioTec. We want to thank P. Perez and S. Fraile (MNCN-CSIC, Madrid, Spain), L. Celia and D. DeMiguel (ICP, Barcelona, Spain), P. Montoya and Ana García Froner (MUVHN, Valencia, Spain), J. Galkin, J. Meng and E. Westwig (AMNH; New York, U.S.A.), P. Brewer and S. Pappa (NHMUK, London, U.K.), C. Argot and S. Peigne (MNHN, Paris, France) and their respective home institutions for giving us access to their giraffid fossil collections. We thank E. Cantero, B. Gómez and P. Gutierrez for the preparation of the BAT10 fossils. We also deeply thank the reviewers and editors of this paper for increasing significantly the value and relevance this study.

\section{FUNDING}

The author(s) reported there is no funding associated with the work featured in this article.

\section{ORCID}

María Ríos (D) http://orcid.org/0000-0001-7242-1259

Jorge Morales (D) http://orcid.org/0000-0001-5170-5754

\section{LITERATURE CITED}

Abel, O. 1904. Über einen Fund von Sivatherium giganteum bei Adrianopel. Sitzungsberichte der MathematischNaturwissenschaftlichen Klasse CXIII:629-652.

Aguirre, E., and J. Morales. 1974. Coloquio Internacional sobre bioestratigrafía continental del Neógeno superior y cuaternario inferior. Libroguia, Madrid.

Aguirre, E., N. López, and J. Morales. 1976. Continental faunas in Southeast Spain related to the Messinian. In Il significato geodinamico della crisi di salinita'del Miocene terminale nel Mediterraneo, Messinian seminar 2:62-63.

Alba, D. M., Delson, E., Morales, J., Montoya, P., and G. Romero. 2018. Macaque remains from the early Pliocene of the Iberian Peninsula. Journal of Human Evolution 123:141-147.

Alcalá, L. 1994. Macromamíferos neógenos de la fosa de AlfambraTeruel, Vol. PhD. dissertation, pp. 554. Instituto de Estudios Turolenses y Museo Nacional de Ciencias Naturales, CSIC, Teruel.

Alcalá, L., and P. Montoya. 1994. Los jiráfidos del Neógeno de la fosa de Teruel. Estudios Geológicos 50:127-137.

Alcalá, L., C. Sesé, E. Herráez, and R. Adrover. 1991. Mamíferos del Turoliense inferior de Puente Minero (Teruel, España). Boletín de la Real Sociedad Española de Historia Natural. Sección Geológica 86:205-251.

Athanassiou, A. 2014. New giraffid (Artiodactyla) material from the Lower Pleistocene locality of Sésklo (SE Thessaly, Greece): evidence for an extension of the genus Palaeotragus into the Pleistocene. Zitteliana B 32:71-89.

Bärmann, E. V., and G. E. Rössner. 2011. Dental nomenclature in Ruminantia: towards a standard terminological framework. Mammalian Biology 76:762-768.

Barone, R. 1999. Anatomie comparée des mammifères domestiques: Ostéologie. Vigot Frères, Paris, 761 pp.

Bohlin, B. 1926. Die Familie Giraffidae. Palaeontologia Sinica C4(I):1170.

Bonaparte, C.L. 1850. Conspectus Systematis Mastozoologiae. Editio Altéra Reformata. In Conspectus Systematum, Leiden.

Bruijn, H. d., P. Mein, C. Montenat, and A. Van De Weerd. 1975. Corrélations entre les gisements de rongeurs et les formations marines du Miocéne terminal d'Espagne méridionale (provinces d'Ali-cante et de Murcia). Proceedings Koninklijke Nederlandse Akademie van Wetenschappen 78:1-32.

Crusafont, M. 1952. Los jiráfidos fósiles de España. Diputación Provincial de Barcelona. Memorias y comunicaciones del Instituto Geológico VIII: Premio extraordinario de Doctorado, 239 pp.

Churcher, C. S. 1978. Chapter 25. Giraffidae; pp. 509-535 in Vincent J. Maglio and H. B. S. Cooke (eds.), Evolution of African Mammals. Harvard University Press.

Dietrich, W. O. 1937. Pleistozäne giraffiden und bovinen aus Oldoway, Deutsch-Ostafrika. Wissenschaftliche Ergebnisse der OldowayExpedition 1913 4:106-110.

Dietrich, W. O. 1942. Ältestquartäre säugetiere aus der südlichen Serengeti, Deutsch-Ostafrika. Palaeontographica XCIV(A):43192.

Falconer, H. 1845. Description of Some Fossil Remains of Dinotherium, Giraffe, and other Mammalia, from the Gulf of Cambay, Western Coast of India, Chiefly from the Collection Presented by Captain Fulljames, of the Bombay Engineers, to the Museum of the Geological Society. Quarterly Journal of the Geological Society $1: 356-372$.

Falconer, H., and P. T. Cautley. 1836. Sivatherium giganteum, a new fossil ruminant genus, from the valley of the Markanda, in the Siválik branch of the Sub-Himalayan Mountains. Journal of the Asiatic Society of Bengal 5:38-50.

Franz-Odendaal, T. A., and N. Solounias. 2004. Comparative dietary evaluations of an extinct giraffid (Sivatherium hendeyi) (Mammalia, Giraffidae, Sivatheriinae) from Langebaanweg, South Africa (early Pliocene). Geodiversitas 26:675-685.

Franz-Odendaal, T. A., A. Chinsamy, and J. Lee-Thorp. 2004. High prevalence of enamel hypoplasia in an early Pliocene giraffid (Sivatherium hendeyi) from South Africa. Journal of Vertebrate Paleontology 24:235-244.

Garrido, G., and A. Arribas. 2008. Notes on the only known population of the giraffid Mitilanotherium (Giraffidae, Artiodactyla, Mammalia) from the late upper Pliocene of western Europe (Fonelas P-1, Guadix Basin, Granada). Vertebrados del Plioceno superior terminal en el suroeste de Europa: Fonelas P-1 y el Proyecto Fonelas. Cuadernos del Museo Geominero 10:397-411.

Gaudry, A. 1861. Animaux Fossiles de L'Attique Résultats des fouilles exécutées en Grèce sous les auspices de l'Académie des sciences. Comptes rendus hebdomadaires des séances de l'Académie des sciences 51:802-804.

Geraads, D. 1996. Le Sivatherium (Giraffidae, Mammalia) du Pliocène final d'Ahl al Oughlam (Casablanca, Maroc), et l'évolution du genre en Afrique. Paläontologische Zeitschrift 70:623-629.

Geraads, D. 2009. Giraffidae (Mammalia) de la fin du Néogène de la République de Macédoine (ARYM). Geodiversitas 31:893-908.

Geraads, D., and R. Bobe. 2020. Ruminants (Giraffidae and Bovidae) from Kanapoi. Journal of Human Evolution 140:102383.

Geraads, D., R. Bobe, and F. K. Manthi. 2013. New ruminants (Mammalia) from the Pliocene of Kanapoi, Kenya, and a revision of previous collections, with a note on the Suidae. Journal of African Earth Sciences 85:53-61.

Gray, J. E. 1821. On the natural arrangement of vertebrate animals. London Medical Repository 15:297-310.

Haile-Selassie, Y. 2009. Chapter 12: Giraffidae; pp. 389-396 in Y. HaileSelassie and G. Wolde (eds.), Ardipithecus kadabba: late Miocene 
evidence from the Middle Awash, Ethiopia. University of California Press.

Harris, J. 1976a. Giraffidae from the East Rudolf succession; in Y. Coppens, F.C. Howell, G.L. Isaac and R.E. Leakey (eds.) Earliest Man and Environments in the Lake Rudolf Basin; pp. 264-267 Chicago University Press, Chicago.

Harris, J. M. 1976b. Pliocene Giraffoidea (Mammalia, Artiodactyla) from the Cape Province. Annals of the South African Museum 69:325-353

Harris, J. M. 1991. Koobi Fora Research Project, Vol. 3: The Fossil Ungulates: Geology, Fossil Artiodactyls, and Paleoenvironments. Clarendon Press, Oxford, 383 pp.

Harris, J. M. 2003. Chapter 11. Lothagam Giraffids; pp. 523-530 in Meave G. Leakey, and Harris, J. M. (eds.), Lothagam. Columbia University Press.

Harris, J. M., N. Solounias, and D. Geraads. 2010. Chapter 39. Giraffoidea; pp. 805-820 in L. Werdelin and W.J. Sanders (eds.), Cenozoic Mammals of Africa, University of California Press.

Harris, J. M., M. G. Leakey, T. E. Cerling, and A. J. Winkler. 2003. Early Pliocene tetrapod remains from Kanapoi, Lake Turkana Basin, Kenya. Contributions in Science 498:39-114.

Hopwood, A. T. 1934. New fossil mammals from Olduvai, Tanganyika Territory. Annals and Magazine of Natural History, 14:546-550

Kalb, J. E., C. J. Jolly, S. Tebedge, A. Mebrate, C. Smart, E. B. Oswald, P. F. Whitehead, C. Wood, T. Adefris, and V. Rawn-Schatzinger. 1982. Vertebrate faunas from the Awash group, Middle Awash Valley, Afar, Ethiopia. Journal of Vertebrate Paleontology 2:237-258.

Kostopoulos, D. S. 2009. The Late Miocene Mammal Faunas of the Mytilinii Basin, Samos Island, Greece: New Collection. 13. Giraffidae. Beiträge zur Paläontologie 31:345-389.

Likius, A. 2002. Les grands ongulés du Mio-Pliocène du Tchad (Rhinocerotidae, Giraffidae, Camelidae): systématique, implications paléobiogéographiques et paléoenvironnementales (Doctoral dissertation, Université de Poitiers, Poitiers).

Linnaeus, C. 1758. Systema Naturae, Ed. X (Systema naturae per regna tria naturae, secundum classes, ordines, genera, species, cum characteribus, diferentiis, synonymis, locis. Tomus I. Editio decima reformata). Laurentii Salvii, Holmiae. Stockholm, 824 pp.

Lydekker, R. 1876. Indian Tertiary and Post-Tertiary Vertebrata. Descriptions of the molar teeth and other remains of Mammalia. Memoirs of the Geological Survey of India. Palaeontologica Indica I (2):19-83.

Mein, P., G. Bizon, J. Bizon, and C. Montenat. 1973. Le gisement de Mammifères de La Alberca (Murcia, Espagne méridionale). Corrélations avec les formations marines du Miocène terminal. Comptes rendus de l'Académie des Sciences 276:3077-3080.

Montenat, C., 1973. Les formations Néogènes et Quaternaires du Levant espagnol (Provinces d'Alicante et de Murcia), PhD. Thesis, Orsay Univ., $1170 \mathrm{pp}$.

Montenat, C., and M. Crusafont. 1970. Découverte de mammiferes dans le Néogene et le Pléistocene du Levant espagnol (provinces d'Alicante et de Murcia). Comptes Rendus de l'Académie des Sciences 270:2434-2437.

Montgelard, C., F. M. Catzeflis, and E. Douzery. 1997. Phylogenetic relationships of artiodactyls and cetaceans as deduced from the comparison of cytochrome $\mathrm{b}$ and $12 \mathrm{~S}$ rRNA mitochondrial sequences. Molecular Biology and Evolution 14:550-559.

Montoya, P., and J. Morales. 1991. Birgerbohlinia schaubi Crusafont, 1952 (Giraffidae, Marnrnalia) del Turoliense inferior de Crevillente-2 (Alicante, España). Filogenia e historia biogeográfica de la subfamilia Sivatheriinae. Bulletin du Muséum National d'Histoire Naturelle 13:177-200.

Morales, J., and D. Soria. 1981. Los artiodáctilos de Los Valles de Fuentidueña (Segovia). Estudios geológicos 37:477-501.

Morales, J., and D. Soria. 1984. Los Artiodáctilos del Mioceno inferior de las cuencas centrales de España. Coloquios de Paleontología, 39:51-59.

Morales, J., P. Peláez-Campomanes, P. Pérez, M. T. Alberdi, B. Azanza, M. Pickford, M. Ríos, O. Sanisidro, G. Alcalde, and J. L. Cantalapiedra. 2018. Neogene mammal sites in Molina de Aragón (Guadalajara, Spain): correlation to other karstic sites of the Iberian Chain, and their geoheritage values. Geoheritage 10:353-362.
Pérez-García, A., E. Vlachos, and X. Murelaga. 2020. A large testudinid with African affinities in the post-Messinian (lower Pliocene) record of south-eastern Spain. Palaeontology 63:497-512.

Piñero, P., J. Agustí, O. Oms, I. Fierro, P. Montoya, S. Mansino, F. RuizSánchez, D. M. Alba, M. T. Alberdi, and H.-A. Blain. 2017. Early Pliocene continental vertebrate Fauna at Puerto de la Cadena (SE Spain) and its bearing on the marine-continental correlation of the Late Neogene of Eastern Betics. Palaeogeography, Palaeoclimatology, Palaeoecology 479:102-114.

Pomel, A. 1892. Sur le Libytherium maurusium, grand ruminant du terrain Pliocène de l'Algérie. Comptes rendus hebdomadaires des séances de l'Académie des sciences 115:100-102.

Popov, S.V., F. Rögl, A.Y. Rozanov, F.F. Steininger, I.G. Shcherba, and M. Kovác, 2004. Lithologicalpaleogeographic maps of Paratethys. 10 Maps Late Eocene to Pliocene. Courier Forschungsinstitut Senckenberg 250:1-46.

Ríos, M., and J. Morales. 2019. A new skull of Decennatherium rex Ríos, Sánchez and Morales, 2017 from Batallones-4 (upper Vallesian, MN10, Madrid, Spain). Palaeontologia Electronica 22:1-16.

Ríos, M., M. Danowitz, and N. Solounias. 2016a. First comprehensive morphological analysis on the metapodials of Giraffidae. Palaeontologia Electronica 19:1-39.

Ríos, M., I. M. Sánchez, and J. Morales. 2016b. Comparative anatomy, phylogeny, and systematics of the Miocene giraffid Decennatherium pachecoi Crusafont, 1952 (Mammalia, Ruminantia, Pecora): state of the art. Journal of Vertebrate Paleontology 36:e1187624.

Ríos, M., I. M. Sánchez, and J. Morales. 2017. A new giraffid (Mammalia, Ruminantia, Pecora) from the late Miocene of Spain, and the evolution of the sivathere-samothere lineage. PLOS ONE 12: e0185378.

Roberts, D. L., T. Matthews, A. I. Herries, C. Boulter, L. Scott, C. Dondo, P. Mtembi, C. Browning, R. M. Smith, and P. Haarhoff. 2011. Regional and global context of the Late Cenozoic Langebaanweg (LBW) palaeontological site: West Coast of South Africa. Earth-Science Reviews 106:191-214.

Robinson, C. A. 2011. Chapter 14. Giraffidae; pp. 339-362 in T. Harrison (ed.) Paleontology and Geology of Laetoli: Human Evolution in Context: Volume 2: Fossil Hominins and the Associated Fauna. Springer Science \& Business Media, Dordrecht.

Samson, P., and C. Radulesco. 1966. Sur la présence des Giraffidés dans le Villafranchien supérieur de Roumanie. Neues Jahrbuch für Geologie und Paläontologie 10:558-594.

Scopoli, G.A. 1777. Introductio ad historiam naturalem, sistens genera lapidium, planatarum, et animalium hactenus detecta, caracteribus essentialibus donata, in tribus divisa, subinde ad leges naturae. Prague, Gerle, 506 pp.

Singer, R., and E. Boné. 1960. Modern giraffes and the fossil giraffids of Africa. Annals of the South Africa Museum, 45:375-548.

Solounias, N. 2007. Family Giraffidae; pp. 257-277 in D. R. Prothero and and S. E. Foss (eds.), The Evolution of Artiodactyls. The Johns Hopkins University Press, Baltimore.

Solounias, N., and M. Danowitz. 2016. Astragalar morphology of selected Giraffidae. PLOS ONE 11:e0151310.

Valenciano A., and R. Govender. 2020. New insights into the giant mustelids (Mammalia, Carnivora, Mustelidae) from Langebaanweg fossil site (West Coast Fossil Park, South Africa, early Pliocene). PeerJ 8:e9221.

van der Made, J., and J. Morales. 2011. Mitilanotherium inexpectatum (Giraffidae, Mammalia) from Huélago (Lower Pleistocene; Guadix-Baza basin, Granada, Spain) observations on a peculiar biogegraphic pattern. Estudios geológicos 67:613-627.

von den Driesch, A. 1976. A guide to the measurement of animal bones from archaeological sites: as developed by the Institut für Palaeoanatomie, Domestikationsforschung und Geschichte der Tiermedizin of the University of Munich. Harvard University Press, Cambridge, 1136 pp.

Submitted August 12, 2020; revisions received August 3, 2021; accepted August 13, 2021.

Handling Editor: Faysal Bibi. 